\title{
The S1P-S1PR Axis in Neurological Disorders-Insights into Current and Future Therapeutic Perspectives
}

\author{
Alexandra Lucaciu ${ }^{1, * \mathbb{D}}$, Robert Brunkhorst ${ }^{2}$, Josef M. Pfeilschifter ${ }^{3}$, Waltraud Pfeilschifter ${ }^{1}$ \\ and Julien Subburayalu $4, *$ (D) \\ 1 Department of Neurology, University Hospital Frankfurt, Goethe University Frankfurt, \\ 60528 Frankfurt am Main, Germany \\ 2 Department of Neurology, RWTH Aachen University, 52074 Aachen, Germany \\ 3 Institute of General Pharmacology and Toxicology, Pharmazentrum Frankfurt, Goethe University Frankfurt, \\ 60528 Frankfurt am Main, Germany \\ 4 Department of Medicine, Addenbrooke's Hospital, University of Cambridge, Cambridge CB2 0QQ, UK \\ * Correspondence: Alexandra.Lucaciu@kgu.de (A.L.); js2380@cam.ac.uk (J.S.)
}

Received: 14 May 2020; Accepted: 19 June 2020; Published: 22 June 2020

check for updates

\begin{abstract}
Sphingosine 1-phosphate (S1P), derived from membrane sphingolipids, is a pleiotropic bioactive lipid mediator capable of evoking complex immune phenomena. Studies have highlighted its importance regarding intracellular signaling cascades as well as membrane-bound S1P receptor (S1PR) engagement in various clinical conditions. In neurological disorders, the S1P-S1PR axis is acknowledged in neurodegenerative, neuroinflammatory, and cerebrovascular disorders. Modulators of S1P signaling have enabled an immense insight into fundamental pathological pathways, which were pivotal in identifying and improving the treatment of human diseases. However, its intricate molecular signaling pathways initiated upon receptor ligation are still poorly elucidated. In this review, the authors highlight the current evidence for S1P signaling in neurodegenerative and neuroinflammatory disorders as well as stroke and present an array of drugs targeting the S1P signaling pathway, which are being tested in clinical trials. Further insights on how the S1P-S1PR axis orchestrates disease initiation, progression, and recovery may hold a remarkable potential regarding therapeutic options in these neurological disorders.
\end{abstract}

Keywords: sphingosine 1-phoshate; sphingosine 1-phosphate receptor; $\mathrm{S}_{1} \mathrm{P}_{1-5}$; sphingosine 1-phosphate metabolism; sphingosine 1-phosphate antagonistst/inhibitors; sphingosine 1-phosphate signaling; stroke; multiple sclerosis; neurodegeneration; fingolimod

\section{Introduction-S1P Metabolism and Signaling}

Three decades ago, sphingosine 1-phosphate (S1P) was identified as an intracellular signaling agent in relation to calcium release from intracellular stores and metabolic adaptations [1]. The balance between sphingosine and S1P, both metabolites of its precursor ceramide, and their subsequent activation of effector kinases were shown to matter in imposing regulatory effects in the determination of whether a cell is destined for cell death or proliferation [2]. The sphingolipid metabolism is almost as complex as its protean intricacies to signaling pathways.

\subsection{De Novo Sphingolipid Synthesis and Signaling at the Endoplasmic Reticulum}

De novo sphingolipid biosynthesis is initiated in the smooth endoplasmic reticulum (sER) (Figure1). Here, the $\alpha$-aminocarbonic acid serine and the lipid palmitoyl-CoA (PalCoA) are enzymatically 
processed by the key enzyme serine palmitoyltransferase (SPT) — which is negatively regulated by ORM1-like protein 3 (ORMDL3) [3]-to 3-ketosphinganine [4-6]. Subsequent conversion of 3-ketosphinganine to S1P is promoted by enzymatic reactions including a reduction to sphinganine, a synthase reaction to dihydroceramide, and a desaturase reaction to ceramide followed by deacylation by ceramidase (CDase) and a phosphorylation by sphingosine kinase (SphK), which exists in two isoforms (SphK1 and SphK2) [6-8]. In general, the formation of the ceramide and the sphingoid bases represents the backbone of the sphingolipid metabolic pathway, as they can be utilized for the synthesis of complex glycosphingolipids. Glycosphingolipids are crucial components of cellular membranes $[4,9]$, such as glucosylceramide or sphingomyelin manufactured by glucosylceramide synthase (GCS) or sphingomyelin synthase (SMS), respectively $[10,11]$. These various enzymatic reactions are not irreversible per se, since ceramide can be generated by sphingomyelin hydrolysis and/or recycling of complex sphingolipids $[10,12,13]$. Ultimately, S1P can irreversibly be degraded by S1P lyase into phosphoethanolamine (PE) and hexadecenal, both of which are being further processed [14,15]; PE is used for the synthesis of phosphatidylethanolamine and hexadecenal is used to replenish the PalCoA pool [15-18]. This cycle of de novo sphingolipid synthesis is tightly controlled by NOGO-B, a protein located within the membrane of the endoplasmic reticulum, which inhibits SPT $[19,20]$. Alternatively, S1P can be converted back to ceramides by dephosphorylation through sphingosine 1-phosphate phosphatase (SGPP) 1 or SGPP2 [21,22], both of which are members of the lipid phosphate phosphohydrolase (LPP) family [23]. This pathway can substantially contribute to the synthesis of complex sphingolipids within a cell subject to cell type and metabolic demand [24,25].

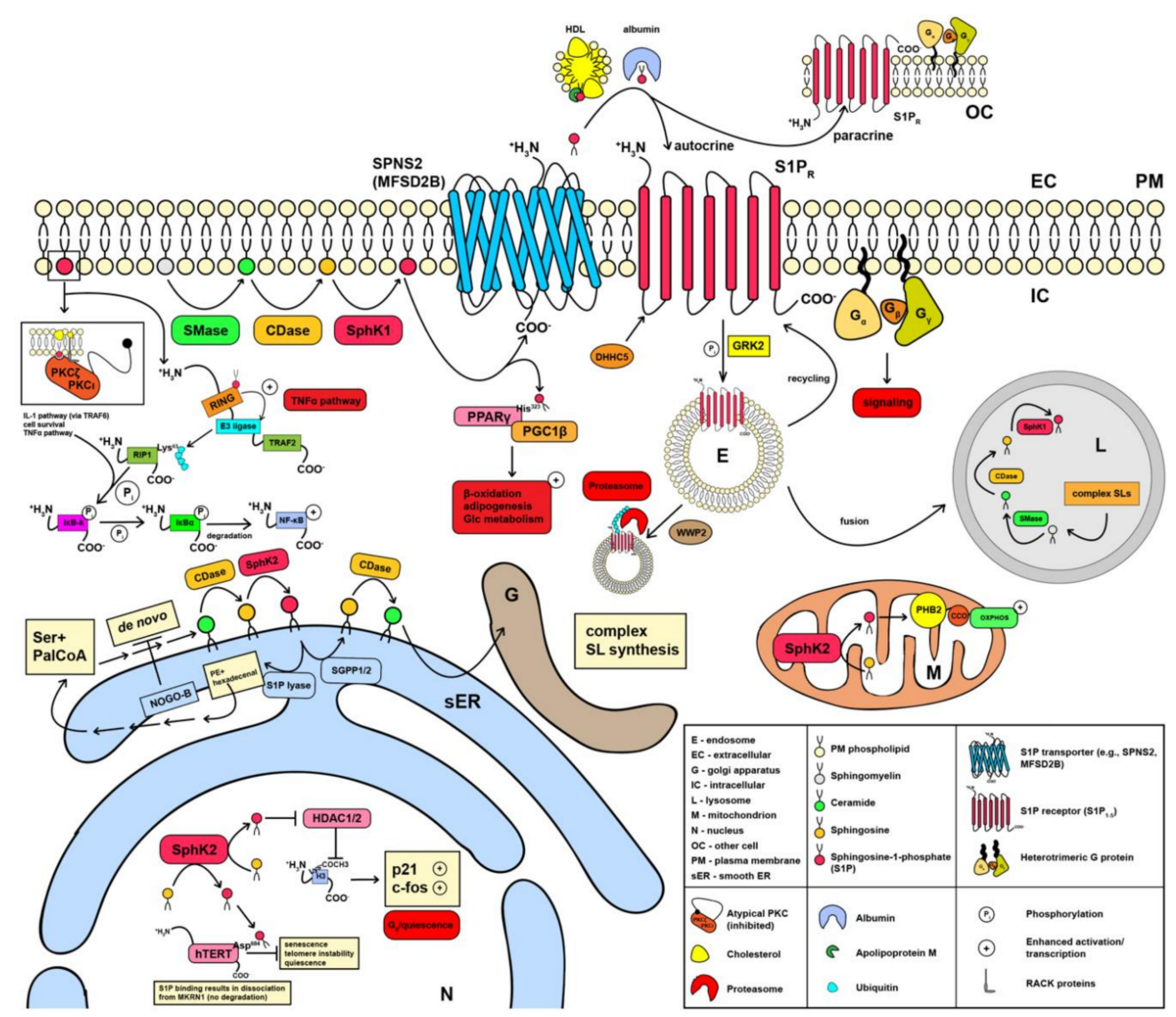

Figure 1. Sphingolipid biosynthesis, sphingosine 1-phosphate (S1P) release, and signaling. S1P is generated in different compartments within a cell. Nuclear S1P influences the balance between chromosome density by histones and telomere length impacting on metabolic adaptations and cell proliferation. De novo S1P synthesized at the smooth endoplasmic reticulum may be utilized for complex 
sphingolipid synthesis, crucial components of cellular membranes. Mitochondrial S1P influences mitochondrial respiration by activating complex IV. S1P generated at the intracellular leaflet of the plasma membrane (PM) is either used for intracellular signaling converging on the TNF $\alpha$ or the PPAR $\gamma$ pathways or is exported to induce autocrine or paracrine stimulation transported by apolipoprotein (ApoM)-containing high-density lipoprotein (HDL) or albumin and signaling via membrane-bound S1P receptor (S1PR). Intracellularly, S1PR recruit different heterotrimeric G proteins to initiate different signaling pathways, which results in the down-regulation of S1PR via $\beta$-arrestin dependent recruitment of $G$ protein receptor $\beta$-arrestin-regulated kinase 2 (GRK2), allowing dynamin and moesin-dependent endosome recruitment. Endosomal S1PR are either recruited to the PM or polyubiquitinylated by NEDD4-like E3 ubiquitin ligase WWP2 (WWP2) targeting S1PR for proteasomal degradation. Endosomal remnants are fused with the lysosome (the place where complex sphingolipids are degraded) to fully degrade proteinaceous or lipid cargo, ultimately replenishing the S1P pool. The figure is a modified version of Cartier and Hla [26] and Kunkel et al. [23].

\subsection{Synthesis and Signaling of Sphingosine 1-Phosphate in Mitochondria and at the Plasma Membrane}

MitochondrialS1P (Figure 1), produced by SphK2, facilitates oxidative phosphorylation (OXPHOS). This effect was shown to be mediated by stabilizing the scaffolding protein prohibitin-2 (PHB2), which, in turn, eases the recruitment of cytochrome c oxidase (CCO) and thus the assembly of complex IV of the respiratory chain $[23,27]$. The most important site of S1P production is the plasma membrane (PM) itself (Figure 1), which is composed of a lipid bilayer, predominantly consisting of an extracellular (EC) and an intracellular (IC) phospholipid leaflet. Here, S1P is derived from sphingomyelin, an integral component of cellular membranes [4]. Sphingomyelin is metabolized to S1P via the enzymes sphingomyelinase (SMase), CDase, and sphingosine kinase 1 (SphK1) [28,29]. At this point, S1P can either be exported using the multi-pass membrane proteins spinster homolog 2 (SPNS2) [30-33] or major facilitator superfamily domain-containing protein 2B (MFSD2B) [30-32], respectively, or employed for further immediate intracellular signaling cascades. In terms of intracellular signaling, S1P can engage in tumor necrosis factor- $\alpha$ (TNF- $\alpha$ ) receptor-associated factor 2 (TRAF2) [34] and TRAF6-dependent TNF- $\alpha$ signaling [35]. S1P can either recruit the atypical protein kinase C (PKC) subtypes $\zeta(\mathrm{PKC} \zeta)$ or $\iota(\mathrm{PKC} \mathrm{l})$ to sites of distinct membrane microdomains using receptor for activated C kinase (RACK) proteins [36-38] or associate with the TRAF2 complex [34]. This, in turn, allows the activation of the interleukin-1 (IL-1) pathway via TRAF6, cell survival, and convergence on the TNF- $\alpha$ pathway downstream of TRAF2 [28,34,39-41]. The association with the TRAF2 complex is said to occur by engaging with the N-terminal adjacent really interesting new group (RING) domain, which allows activation of the intramolecular E3 ligase domain of TRAF2 [28,34,41]. The activation of TRAF2's E3 ligase lures receptor-interacting serine/threonine-protein kinase 1 (RIP1) in close proximity, allowing polyubiquitination of its Lys ${ }^{63}$ residue. Polyubiquitination of Lys ${ }^{63}$ stimulates RIP1's kinase activity, which results in the phosphorylation of the inhibitor of nuclear factor $\mathrm{k}-\mathrm{B}$ kinase (I $\kappa \mathrm{B}-\mathrm{k})$. As a consequence, the nuclear factor $k$-light-chain-enhancer of activated B cells (NF- $k \mathrm{~B})$ signaling pathway is engaged, since I $k B-k$ is now able to facilitate the down-regulation of the NF- $k B$ inhibitor $\alpha(\mathrm{I} \kappa \mathrm{B} \alpha)$. This culminates in the uncoupling of $\mathrm{I} \kappa \mathrm{B} \alpha$ from NF- $\kappa \mathrm{B}$ revoking its inhibitory effect and allowing NF-KB's nuclear translocation $[28,34,35]$. Crosstalk between TRAF2 and TRAF6 was previously reported, as both can engage with atypical PKCs via protein p62 [39], are able to recruit TGF- $\beta$-activated kinase 1 and MAP3K7-binding protein 3 (TAB3) [40,42], or can be polyubiquitinylated given the presence of a RING domain in TRAF6 [43]. Moreover, a disruption of TRAF6 binding sites, for example, only mildly impacts NF-KB signaling in the presence of TRAF2 and TRAF3 [44]. Beyond the TNF- $\alpha$ signaling pathway, S1P signaling can vitalize adipogenesis, glucose (Glc) metabolism, and $\beta$-oxidation via peroxisome proliferator activated receptor $\gamma(\operatorname{PPAR} \gamma)[15,45,46]$. By binding to its $\mathrm{His}^{323}$ residue, S1P activates PPAR $\gamma$, increasing the likelihood of an association with the PPAR $\gamma$ co-activator $1 \beta$ (PGC1 $\beta)$, a necessary co-transcription factor for nuclear translocation $[46,47]$. 


\subsection{Sphingosine 1-Phosphate Signaling in the Nucleus}

SphK2, the predominant isoform in the sER and mitochondria [27,48], is also predominant in the nucleus (Figure 1) [49-53]. Nuclear S1P was shown to be critically involved in influencing the balance between cellular quiescence and proliferation. Hait et al., showed that S1P produced in the nucleus binds to the class I histone deacetylases (HDAC) 1 and 2, which results in their inhibition [53]. In general, HDAC1 and HDAC2's function lies in removing acetyl residues coupled to the $\alpha$-aminocarbonic acid lysine close to the amino-terminal end of the histone protein H3 [54-56]. Therefore, the removal of these negatively charged residues culminates in a net positive charge of $\mathrm{H} 3$, increasing its tight association with the negatively charged deoxyribonucleic acid (DNA). Ultimately, the inhibition of HDAC1/2 enhances transcription of cyclin-dependent kinase inhibitor 1 (p21) and the proto-oncogene c-Fos (c-fos) [53]. Conversely, S1P may bind to human telomerase reverse transcriptase (hTERT) [57], which may allow makorin ring finger protein 1 (MKRN1) to dissociate due to competitive binding sites $[57,58]$. This signaling cascade results in telomere maintenance, cell proliferation, and tumor growth [57].

\subsection{Sphingosine 1-Phosphate in Autocrine and Paracrine Signaling}

Detailed experimental evidence is available for the mechanisms of "inside-out" autocrine and paracrine S1P signaling. After release into the extracellular compartment via SPNS2 [30-33] or MFSD2B [30-32], S1P is swiftly bound by its chaperones due to its hydrophobic character. These chaperones are apolipoprotein M (ApoM)-containing high-density lipoprotein (HDL)-to some extent also to very low-density lipoprotein (VLDL) and low-density lipoprotein (LDL) [59,60]—or albumin, respectively [61-63]. Subsequently, upon release and chaperoning by HDL or albumin, ligation of the five known heptameric $G$ protein-coupled S1P receptors (S1PR) 1-5 (S1P ${ }_{1-5}$ ) (Figure 1) [64-69] can result both in autocrine and paracrine signaling [70-72]. Signaling via S1PR is tightly regulated. Fine tuning of S1P-S1PR signaling may occur via post-translational modifications, e.g., through palmitoylation by the palmitoyltransferase DHHC5 (DHHC5) [73] and, at some point, termination of the signaling cascade may be achieved by $\beta$-arrestin-dependent recruitment of $G$ protein-coupled receptor kinase 2 (GRK2), which phosphorylates S1PR, resulting in dynamin and moesin dependent establishment of the endosome [74-79]. At this point, re-routing, i.e., recycling of the receptor to the PM [80], polyubiquitination by the NEDD4-like E3 ubiquitin protein ligase WWP2 (WWP2) resulting in proteasomal degradation [81], or fusion with the lysosome in order for complete proteinaceous and lipid residue degradation can occur (Figure 1) [82-84]. The latter endolysosomal salvage pathway is of particular importance for cellular homeostasis and disassembly of complex sphingolipids to ceramides or allowing endolysosomal SphK1 to produce S1P, respectively [85-87]. The herein discussed mechanisms are briefly summarized in Figure 1.

\subsection{External Action of Sphingosine 1-Phosphate through S1PR}

With respect to S1PR ligation, the de facto signal triggered is dependent upon the S1PR subtype, the presence of co-regulatory agents, and the heterotrimeric $\mathrm{G}$ protein recruited. To date, five bona

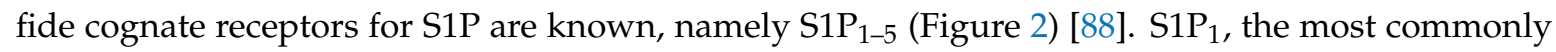
expressed S1P receptor in the brain [89], appears to be most selective as it binds only to $G \alpha_{\mathrm{i} / 0}[66,90]$. $\mathrm{S}_{1} \mathrm{P}_{2}$, also binding to $\mathrm{G} \alpha_{\mathrm{i} / 0}$, is capable of associating with $\mathrm{G} \alpha_{\mathrm{q}}, \mathrm{G}_{12 / 13}$, and $\mathrm{G} \alpha_{\mathrm{s}}[66,88,90]$, however, it couples most efficiently with $\mathrm{G}_{12 / 13}$, subsequently activating the small GTPase Rho [91-93]. S1P $\mathrm{P}_{3}$ is said to couple with $G \alpha_{i / 0}, G \alpha_{q}$, and $G_{12 / 13}$, although a higher affinity/likelihood for association with $G \alpha_{\mathrm{q}}$ was observed, ultimately resulting in intracellular $\mathrm{Ca}^{2+}$ enrichment and activation of PKC [92,94]. $\mathrm{S}_{4} \mathrm{P}_{4}$ and ${\mathrm{S} 1 \mathrm{P}_{5}}_{5}$ can couple to $\mathrm{G} \alpha_{\mathrm{s}}, \mathrm{G} \alpha_{\mathrm{q}}$, and $\mathrm{G}_{12 / 13}$ [88,95]. Regarding the intracellular signaling pathways triggered, the interested reader is referred to reviews entirely dedicated to detailing molecular signaling and transcriptional cascades triggered in appreciation of the heterotrimeric $G$ protein recruited [96-99]. Regarding receptor activation or inhibition due to the presence of co-regulatory agents, $\mathrm{S}_{1} \mathrm{P}_{1}$ can be 
activated by cluster of differentiation molecule (CD) 44 (CD44) (hyaluronic acid receptor) or activated Protein C (aPC) $[100,101]$, whilst inhibition by CD69, S1P $_{2}$ (in dermal $\gamma \delta \mathrm{T}$ cells), or $\mathrm{LPA}_{1}$ was reported previously [102-104]. Unlike NOGO-B, NOGO-A, a multi-pass PM and ER protein whose expression is confined to the central nervous system (CNS), was shown to activate the S1P binding domain $\Delta 20$ of $\mathrm{S}_{1} \mathrm{P}_{2}$, thereby restricting neurite outgrowth via engagement with the $\mathrm{G}_{13}-\mathrm{RhoA}$ signaling pathway [105]. Moreover, conjugated bile acids (CBAs) and FAM19A5 were other activators of $\mathrm{S}^{\mathrm{P}} \mathrm{P}_{2}[106,107]$. Figure 2 gives a synopsis signaling cascades upon $\mathrm{S}_{1-5}$ ligation.

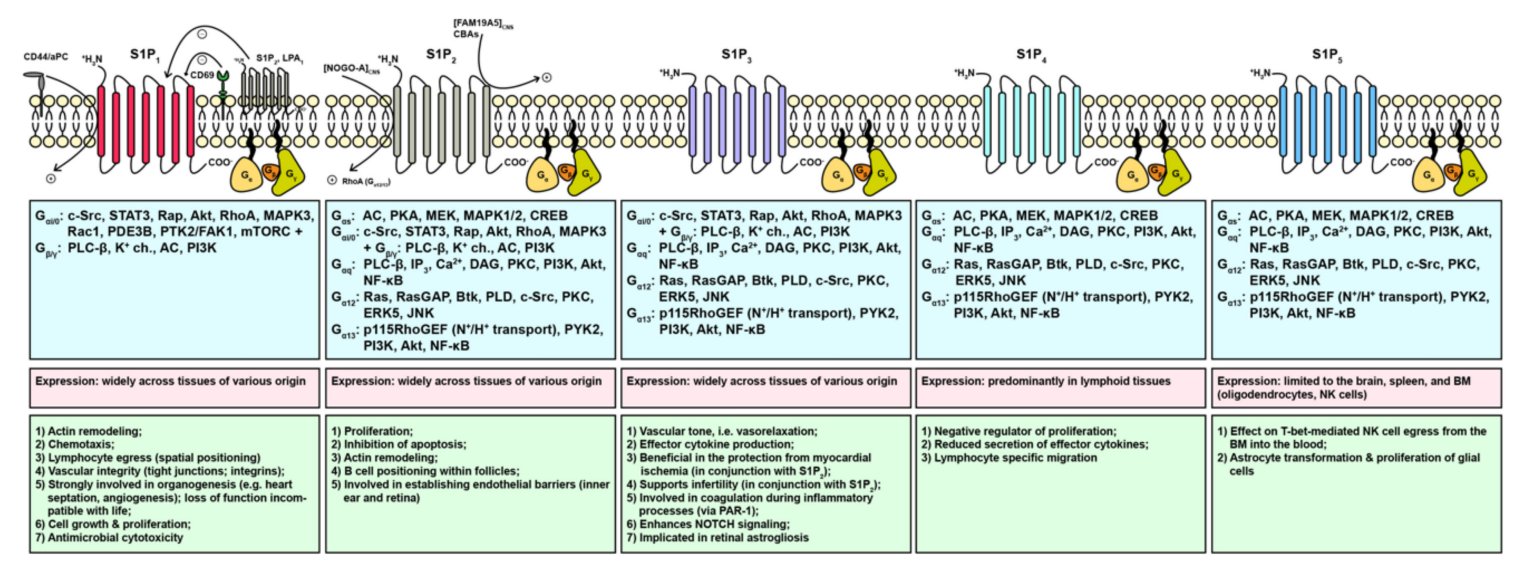

Figure 2. Sphingosine 1-phosphate receptors, canonical pathways, and functions triggered. The currently discovered S1P receptors $1-5\left(\mathrm{~S}_{1} \mathrm{P}_{1-5}\right)$ are displayed. S1PR are naturally activated by S1P and to some extent by dihydro-S1P (sphinganine 1-phosphate) and phyto-S1P (4-hydroxysphinganine 1-phosphate), but also competitive/allosteric activation and inhibition by other molecules are described. Upon activation, S1PR can recruit various heterotrimeric $G$ proteins, which, in turn, allow a finely tuned intracellular signaling cascade to be evoked by means of both $\mathrm{G} \alpha$ and $\mathrm{G} \beta \gamma$. Thus, differential S1PR expression in response to varying environmental lipid contexts, i.e., S1P, dihydro-S1P, and phyto-S1P, respectively, may result in a context- and cell type-dependent function triggered.

\section{Implications of Sphingolipids in Neurological Disorders}

\subsection{The Sphingolipid Metabolism in Neurodegenerative Disorders}

Neurodegenerative diseases are commonly characterized by intracellular or extracellular aggregation of misfolded proteins. These diseases most commonly comprise Alzheimer's disease (AD), characterized by the proteins amyloid- $\beta$ and tau, Parkinson's disease (PD; $\alpha$-synuclein), and amyotrophic lateral sclerosis (ALS), in which TAR DNA-binding protein 43 deposition is observed [108]. With respect to the accumulation of the ontogeny of the protein misfolded, different classifications of neurodegenerative conditions were established, denoted as tauopathies [109], synucleinopathies [110], or prion diseases [111] (Figure 3).

Regarding $\mathrm{AD}$, increasing evidence supports the crosstalk between sphingolipids and aberrant protein aggregation $[112,113]$. Amyloid- $\beta$-peptide $(A \beta)$ is cleaved from amyloid precursor protein (APP) by the $\beta$ - and the $\gamma$-secretase enzymes, while $\alpha$-secretase acts within the A $\beta$ sequence [114]. APP cleavage and the release of $A \beta$ from the PM subsequent to its production in lipid rafts are influenced by lipid composition $[115,116]$. Alterations in membrane lipid composition have a key role in the subsequent subcellular transport and trafficking of these proteins $[114,116,117]$.

Perturbations in the neurovascular unit (NVU) result in a compromised barrier function and dysregulation and reduction in cerebral blood flow (CBF), which is implied to be involved in the pathogenesis of AD [118-127]. Vascular tightness via tight junctions is influenced by the sphingolipid metabolism. In that regard, acid SMase activity and ceramide production in endothelial cells were linked to vascular permeability [128]. Conversely, the acid SMase inhibition maintained enhanced tight junction regulation [128]. Similar mechanisms were observed to happen in astrocytes [129]. In brain 
tissue of AD patients', studies showed increased ceramide levels and decreased sphingomyelin and S1P levels [130-134]. A study on AD by Katsel et al., found a significant up-regulation of messenger ribonucleic acid (mRNA) of phospholipid phosphatase 3 (PLPP3) and S1P lyase 1 (SGPL1) at early stages after diagnosis, suggesting a lack of S1P as a spatiotemporal function may contribute to the degeneration of neurons [135]. Besides, Ceccom et al., reported in an immunohistochemical study of $\mathrm{AD}$ a reduction of SphK1 accompanied by enhanced S1P lyase expression in frontal and entorhinal human cortices to be accountable for the perturbed S1P metabolism observed, contributing to the deposition of amyloid and ultimately to neuronal damage [136]. More recently, Dominguez et al., described that the subcellular localization of S1P's production, e.g., by a disrupted equilibrium between cytosolic and nuclear SphK2, conferred pathogenic effects of S1P in AD [137].
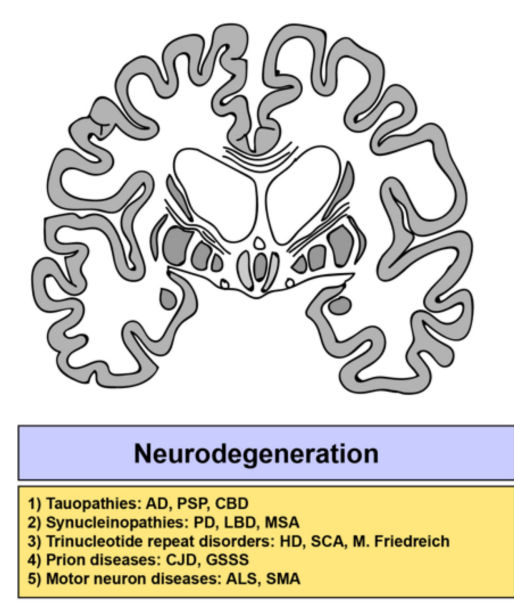
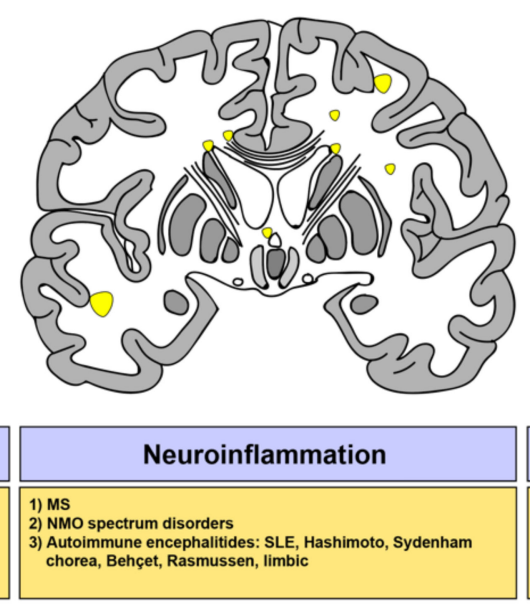

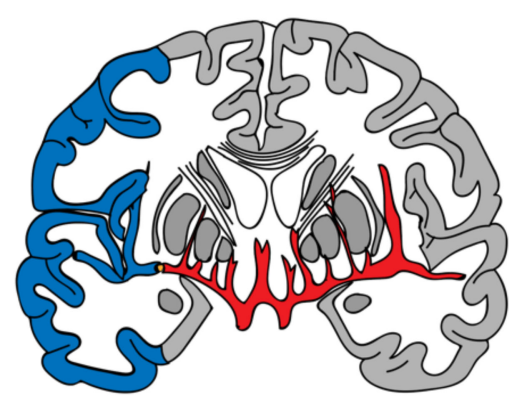

Vascular insults

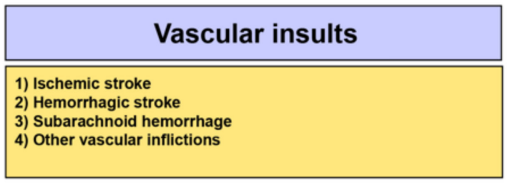

Figure 3. Clinical significance of distorted sphingosine 1-phosphate signaling in neurological disorders. Perturbed S1P signaling has been reported in various clinical conditions ranging from autoimmunity, infection, and cancer. S1P signaling was also shown to play a detrimental role in several neurological diseases, including neurodegenerative and neuroinflammatory conditions, but equally in cerebrovascular insults resulting in stroke or subarachnoid hemorrhage. The yellow patches refer to demyelinated/inflamed areas in the white matter. The area of the grey matter (grey) highlighted in blue denotes the infarcted region. This region is perfused by the middle cerebral artery (here blocked by an embolus), a branch of the cerebral vessel system (red).

With respect to $\mathrm{PD}$, a chronic progressive disorder characterized by the degeneration of dopaminergic neurons in the pars compacta of the substantia nigra, emerging evidence has elucidated the role of mitochondrial and endolysosomal pathways and their interplay with ceramides in its pathogenesis. Xilouri et al., focused on $\alpha$-synuclein degradation and suggested, in 2008, an impairment of neural autophagy-lysosomal pathways to be responsible for $\alpha$-synuclein accumulation, unraveling a causal link between the pathogenic event and the initiation as well as the progression of the disease [138]. Later, further studies confirmed this hypothesis $[139,140]$.

Glucocerebrosidase (GBA) mutations were found in subjects with parkinsonism [141,142], which were previously reported to predispose to the development of Lewy body disorders (LBD) [143]. Concerning LBD, Bras et al., investigated the neuronal ceramide metabolism and reported that several genes known to confer the risk of LBD development converge on the ceramide metabolism, although this remains to be confirmed neurohistologically [144]. In addition, implications in the pathogenesis of synucleinopathies were supported by descriptions of mutations in the GCase gene (GBA1) and altered sphingolipid pathways $[145,146]$.

Mazzulli et al., could delineate that glucosylceramidase (GlcCer), the GCase substrates, enhanced the rate of $\alpha$-synuclein oligomerization [147]. Recently, it was shown that the actual sphingolipid subspecies carry various potentials to cause formation of oligomeric $\alpha$-synuclein, particularly in 
reflection of comparing in vitro with in vivo data [148]. Here, glucosylceramide, glucosylsphingosine, sphingosine, and S1P were shown to promote $\beta$-sheeted (oligomerized) structures of $\alpha$-synuclein [148].

Somewhat aside of the molecular establishment of the aforementioned classifications, neurodegeneration is associated with the accumulation of most commonly CAG trinucleotide repeats, which encode for multiple glutamine residues to be translated, inevitably causing a toxic gain of function of the mutant protein [149]. The best-known condition for trinucleotide repeat disorders is Huntington's disease (HD) [150]. In HD, Di Pardo et al., showed an increase in SGPL1 in the striatum and the cortex and a decrease of SphK1 in the striatum of human post-mortem tissues, which were reflected by similar changes in mouse models of HD [151]. Moreover, the R6/2 mouse model revealed reduced levels of S1P [151,152] despite an up-regulation of SphK2. In contrast, no change was seen in either SphK2 in the YAC128 model or in humans [151]. Unfortunately, no data are currently available regarding S1P levels in YAC128 mice nor in human post-mortem tissues [153]. These findings warrant further investigations into the usability of druggable targets within the sphingolipid metabolism in HD.

Regarding ALS, a study by Henriquez et al., demonstrated a link between ALS severity and gene expressions or metabolite levels for sphingosine, ceramide (d18:1/26:0), SGPP2, SphK1, and UDP galactosyltransferase 8A (UGT8A) [154]. Shedding light on the therapeutic potential of the sphingolipid metabolism in ALS, Potenza et al., reported an improved neurological phenotype and an extended survival after fingolimod, a prodrug that becomes phosphorylated after application in vivo and acts as a receptor agonist against almost unanimously all S1PR—except for $\mathrm{S1P}_{2}[155,156]$, administration in mSOD1 ${ }^{\mathrm{G} 93 \mathrm{~A}}$ mice [157].

\subsection{The Sphingolipid Metabolism in Neuroinflammatory Disorders}

Multiple sclerosis (MS) represents an inflammatory disorder of the brain and the spinal cord featuring inflammation, demyelination, and neurodegeneration [158] (Figure 3). Over the last decades, murine experimental autoimmune encephalomyelitis (EAE) models have been used to decipher the mechanisms responsible for disease pathogenesis and progression and to identify druggable targets in order to develop therapeutics for multiple sclerosis [159-161]. It has been known for some time that the S1P metabolism can be exploited to slow disease progression in MS, e.g., by fingolimod, causing lymphocyte sequestration and ultimately preventing auto-reactive immune cell infiltration into the CNS [162]. The potency of exploiting the S1P-S1PR axis by fingolimod in EAE was first shown in rats by Brinkmann et al. [155], implicating the feasibility to exploit S1PRs to influence lymphocyte egress. Subsequently, other studies have added to this observation [163-165]. Another report unveiled that prophylactic and therapeutic treatment with fingolimod resulted in suppression of EAE [166]. Choi et al., reported, in 2011, that a decline in disease severity of EAE by fingolimod involved astrocytic $\mathrm{S1P}_{1}$ modulation as well, thus a loss of $\mathrm{S}_{1} \mathrm{P}_{1}$ in astrocytes reduced disease severity, demyelination, axonal loss, and astrogliosis [167], arguing for additional CNS-specific effects of fingolimod in addition to lymphocyte redistribution. A recent study identified potential long-term effects caused by S1PR ligation. These long-term effects, according to Eken et al., confer an impact not only on lymphoid sequestration but similarly on non-lymphoid tissue regulatory $\mathrm{T}$ cell $\left(\mathrm{T}_{\mathrm{REG}}\right)$ distribution, and, more importantly, on reducing the memory $\mathrm{T}_{\text {REG }}$ pool in favor of effector $\mathrm{T}_{\text {REG }}$ [168]. This could have implications for appropriate $\mathrm{T}$ cell zone access in lymph nodes via $\mathrm{C}-\mathrm{C}$ chemokine receptor type 7 (CCR7) and subsequently their ability to control auto-reactive $T$ cells in vivo $[168,169]$. These findings warrant further investigation into the precise mechanisms by which enzymes and lipids involved in the generation of S1P and their effects were linked to disease progression and treatment.

Cruz-Orengo et al., identified $\mathrm{S}_{1} \mathrm{P}_{2}$ in the inbred SJL mouse strain as a sex- and strain-specific, disease-modifying molecule promoting the breakdown of adherens junctions, thus leading to blood-brain barrier (BBB) leakage, while antagonism of $\mathrm{S}_{1} \mathrm{P}_{2}$ signaling led to an amelioration of disease severity in female mice [170]. BBB disruption could also be induced by ceramides, resulting in an increased migration of monocytes [129]. Moreover, Lopes et al., demonstrated that acid 
SMase-derived ceramide regulates intracellular adhesion molecule 1 (ICAM-1) function during T cell transmigration across brain endothelial cells [171].

Concerning S1P receptor expression profiles in the disease model of EAE, mRNA for $\mathrm{S}_{1} \mathrm{P}_{1}$ and $\mathrm{S}_{1} \mathrm{P}_{5}$ in the spinal cord was down-regulated, and an up-regulation of $\mathrm{S}_{3} \mathrm{P}_{3}$ and $\mathrm{S}_{1} \mathrm{P}_{4}$ mRNAs occurred in the EAE model, which was reversable by fingolimod in accordance with structural restoration of the CNS parenchyma given a restriction to autoimmune $\mathrm{T}$ cell infiltration [166]. $\mathrm{S1P}_{3}$ was shown to be involved in promoting systemic inflammation via activation of dendritic cells [172]. Concerning $\mathrm{S}_{3} \mathrm{P}_{3}$ signaling in MS, Fischer et al., suggested that an increased expression of $\mathrm{S}_{3} \mathrm{P}_{3}$ in EAE was likely due to astrocyte activation; however, its actual sequelae regarding detrimental effects (e.g., astrogliosis) and beneficial effects (e.g., remyelination) could not be established [173]. Apart from astrocytes, the same group reported enhanced SphK1 expression in macrophages of MS lesions [173]. A more definitive

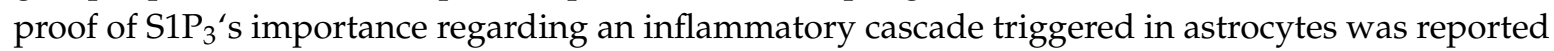
by Dusaban et al. [174]. The authors demonstrated $\mathrm{S} \mathrm{P}_{3}$ to be up-regulated in astrocytes and to be

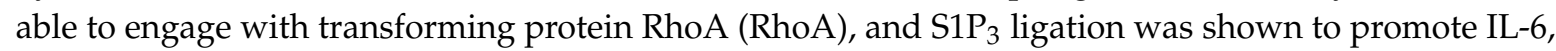
vascular endothelial growth factor A (VEGFa), and cyclooxygenase-2 (COX-2), which was accompanied by an increase of SphK1 and $\mathrm{S}_{3} \mathrm{P}_{3}$ in vitro [174].

Neuromyelitis optica (NMO) spectrum disorders can also be classified as pertaining to the group of inflammatory brain disorders. Their hallmark feature was initially introduced by Devic and Gault $[175,176]$ and characteristically consisted of a severe complement-mediated damage to the optic nerves and the spinal cord [177]. The discovery of highly specific serum autoantibody marker (NMO-IgG) eventually helped to differentiate this spectrum of disorders from MS and the prior interpretation as one entity $[178,179]$. Several reports have suggested that treatment with fingolimod in NMO may be contraindicated due to adverse events and worsening of disease severity [180-183]. However, exploitation of the sphingolipid metabolism to treat patients with NMO should not be excluded prematurely. Matsushita et al., demonstrated significantly higher levels of $\mathrm{T}_{\mathrm{H}}$ 1-related, i.e., C-C motif chemokine 4-like (CCL4) and C-X-C motif chemokine (CXC) 10 (CXCL10), and the $\mathrm{T}_{\mathrm{H}}$-17-related (and neutrophil-related) chemokine CXCL8 (IL-8) in NMO patients [184]. STAT3, which was recently shown to be linked to S1P signaling [185-187], is known to control the expression of chemokines and chemokine receptors in the recruitment of neutrophils [188] and T cells [189]. With respect to the mechanisms by which S1P signaling is tied to chemokine production and immune cell migration, studies revealed an interplay between S1PR and chemokine-driven migration of non-activated and naïve T cells [190]. In addition, binding of S1P produced by SphK1 to TRAF2 and cellular inhibitor of apoptosis 2 (cIAP2) in response to IL-1 signaling results in NF- $\mathrm{kB}$ activation [34]. This represents a relevant step in the recruitment of mononuclear cells to sites of sterile inflammation by means of interferon regulatory factor 1 (IRF1) expression and the resultant availability of the chemokines CXCL10 and CCL5 [191]. Therefore, mediation of the complex pathways of immune cell recruitment/trafficking, potentially resulting in favorable $T_{\text {REG }}$ recruitment without disrupting $T_{H}-17$ or follicular T-helper cell $\left(\mathrm{T}_{\mathrm{FH}}\right)$ sequestration, may hold the potential for future S1P metabolism-associated therapeutic perspectives in NMO [192].

Autoimmune conditions, such as systemic lupus erythematosus (SLE) or Hashimoto's disease, may present themselves with neurological pathology [193-195]. Therefore, due to their clinical heterogeneity, affecting potentially any organ of the body such as renal involvement may advise future neurological therapeutic perspectives. In that regard, studies have shown elevated S1P serum levels in patients with juvenile onset SLE [196] as well as in MRL-lpr/lpr mice [197]. In light of therapeutic targets for SLE, previous studies have concentrated on lupus nephritis. Here, fingolimod showed positive effects on survival, suppressing the continuation of autoimmunity [197]. In the context of murine lupus nephritis, in the NZB/W mouse model as well as in BXSB mice, fingolimod also proved to be beneficial [198-200]. However, inhibition of SphK2 in the MRL-lpr/lpr model could not convey protection from SLE [196]. These promising results prompted testing of cenerimod, a selective $\mathrm{S}_{1} \mathrm{P}_{1}$ modulator (NCT02472795). 
Other conditions denoted by aberrant inflammatory immune cell activation with a potential to cause immune encephalitis have been reported recently. For example, in autoimmune thyroiditis an enhanced expression of SphK1, S1P, and S1P 1 converging on STAT3 activation in $\mathrm{CD}^{+}{ }^{+} \mathrm{T}$ cells was demonstrated in mice by Han et al. [201]. Conversely, administration of fingolimod to these NOD.H- ${ }^{\text {h4 }}$ mice conferred the potential to reduce disease severity accompanied by a reduction of STAT3-related cell types, i.e., $\mathrm{T}_{\mathrm{H}} 1, \mathrm{~T}_{\mathrm{H}} 17$, and $\mathrm{T}_{\mathrm{FH}}$ cells [201].

\subsection{The Sphingolipid Metabolism in Cerebrovascular Diseases}

Lipid signaling plays pleiotropic roles in cerebral ischemia. In recent years, mounting evidence has emerged depicting the relationship between the sphingolipid metabolism and stroke (Figure 3). Studies have demonstrated that the driving force of neuroinflammation following cerebral ischemia are $\mathrm{T}$ cells. They migrate into the brain and amplify the initial detrimental damage [202-205]. Conversely, lymphocyte-deficient mice were shown to be protected from ischemic damage [206,207].

The S1P analogue and the S1P functional antagonist fingolimod, originally derived from the fungal natural product ISP-1, was first synthesized in 1992 [208]. It impairs the egress of lymphocytes from primary and secondary lymphoid organs [155] and exerts immunomodulatory effects and non-immunological mechanisms $[65,167,209-211]$. Fingolimod was shown to provide protection from ischemic stroke and intracerebral hemorrhage [89,204,211-217], leading to the initiation of clinical studies demonstrating the efficacy of fingolimod for patients with acute ischemic stroke and improving clinical outcomes in patients with intracerebral hemorrhage [218]. In addition to reduced infarct volumes and improved neurological scores at 24 and $72 \mathrm{~h}$ after middle cerebral artery occlusion (MCAO; a commonly used animal model for ischemic stroke), fingolimod showed a deactivation of caspase-3, a reduction of terminal deoxynucleotidyl transferase-mediated uridine $5^{\prime}$-triphosphate-biotin nick end-labeling (TUNEL-) positive neurons, an activation of RAC-alpha serine/threonine-protein kinase (Akt) and extracellular-regulated kinase (ERK), and a Bcl-2 up-regulation, delineating an anti-apoptotic effect in neurons [211].

Moreover, studies have reported a role of S1PR in the preservation of endothelial barrier integrity [64,219], and phosphorylated fingolimod promotes the establishment of adherens junction in endothelial cells, i.e., an enhanced endothelial barrier function $[65,209]$.

In contrast, Liesz et al., investigated the effect of fingolimod in permanent murine cerebral ischemia without achieving a significant reduction of infarct volumes and behavioral dysfunction despite effective lymphopenia [220]. In addition, Cai et al., unveiled no improvement in functional outcome and BBB integrity in large hemispheric infarctions and administration of fingolimod, either alone or in conjunction with recombinant-tissue plasminogen activator (rt-PA) [221]. Sanchez suggested that ${\mathrm{S} 1 \mathrm{P}_{1}}_{1}$ desensitization and/or degradation would potentially evoke detrimental effects on neurons and/or endothelial cells in the context of stroke. Therefore, the dosing and the timing of fingolimod administration seemed to be pivotal for its protective effects [222]. This is in accordance with a previous study by Brait et al., who showed that $\mathrm{S}_{1} \mathrm{P}_{1}$ fosters protective effects regarding infarct volume after $\mathrm{MCAO}$, however, only if the associated lymphopenia persists for at least $24 \mathrm{~h}$ [223].

SphK2 appears to wield an ambiguous nature in various disorders. SphK2 is the predominant S1P-synthesizing isoform in normal brain parenchyma [224] and particularly in cerebral microvascular endothelial cells [225]. SphK2 was recently shown to induce ischemic tolerance to stroke in C57BL/6 mice [226]. SphK2 is preferentially utilized to confer the neuroprotective effects of fingolimod, as it has a 30-fold higher affinity to the prodrug compared to SphK1 [225]. Mice lacking the SphK2 show larger ischemic lesions $24 \mathrm{~h}$ after $2 \mathrm{~h}$ of MCAO in comparison with wild-type animals [216], thus reinforcing the importance of extracellular signaling of S1PR. Moreover, studies have demonstrated that SphK2 predominates SphK1 in the phosphorylation of fingolimod in vitro [225] and in vivo [227]. In addition, hypoxia increases the expression and the activity levels of the SphK2 isoform in brain microvasculature, subsequently promoting ischemic tolerance [228]. In contrast to $\mathrm{SphK} 2, \mathrm{~S}_{\mathrm{P}} \mathrm{P}_{2}$ is characterized as a key regulator of the pro-inflammatory phenotype of the endothelium [229] and promotes ischemia-induced 
vascular dysfunction [230]. Conversely, S1P generated by SphK1 potently facilitates the expression of IL-17A in activated microglia, thereby supporting neuronal apoptosis in cerebral ischemia [231]. This is in support of a study by Zheng et al., who found an enhanced expression of SphK1 in microglia $96 \mathrm{~h}$ after MCAO [232]. Subsequently, a cortical knockdown of SphK1 resulted in reduced infarct areas and less severe neurological deficits were observed [232].

Studies have highlighted the critical role of $\mathrm{S}_{1} \mathrm{P}_{2}$ in ischemia-reperfusion injury, confirming that genetic deletion or inhibition of $\mathrm{S}_{1} \mathrm{P}_{2}$ could block the development of hemorrhagic transformation and cerebral edema by inhibiting the matrix metalloproteinase-9 (MMP-9) activation in endothelial cells [230]. It was shown previously that the use of fingolimod conveyed a reduced risk of hemorrhagic transformation after thromboembolic occlusion [233]. In regard to these findings, the benefit of fingolimod in relation to hemorrhagic transformation was tested in randomized open-label multi-center trials [234,235]. Wan et al., focused on microRNA-149-5p and demonstrated its regulatory function on the permeability of the BBB after transient MCAO in rats by targeting $\mathrm{S}_{1} \mathrm{P}_{2}$ of pericytes [236]. In their study, the expression of $\mathrm{S}^{\mathrm{P}_{2}}$ in pericytes increased at an early stage during ischemia/reperfusion, which was associated with an aggravation of BBB permeability in vivo and in vitro [236]. An engineered S1P chaperone, ApoM-Fc, maintained sustained S1P-S1PR signaling, resulting in a promoted function of the BBB after MCAO [237]. Another study puts emphasis on the importance of S1P in ameliorating the effects of stroke, as they reported reduced S1P lyase activity and a preferential synthesis of S1P and other sphingolipids in response to hypoxia [238].

In opposition to $\mathrm{S}_{2} \mathrm{P}_{2}$, pathogenic mechanisms of $\mathrm{S}_{1} \mathrm{P}_{1}$ and $\mathrm{S}_{1} \mathrm{P}_{3}$ in cerebral ischemia rely on microglial activation $[239,240]$. Moreover, the same group elucidated the importance of $\mathrm{S}_{1} \mathrm{P}_{1}$-regulation in promoting a pro-inflammatory M1 polarization of astrocytes, which was brought about by the intracellular signal transducers ERK1/2, p38, and JNK MAPK favoring brain damage after cerebral ischemia [241]. Furthermore, Zamanian et al., examined reactive astrogliosis in response to either MCAO or LPS and showed Pentraxin-related protein PTX3 (PTX3), tumor necrosis factor receptor superfamily member 12A (TNFRSF12A), and $\mathrm{S}_{3} \mathrm{P}_{3}$ to be markers of reactive astrocytes after MCAO [242]. Liddelow et al., termed them "A1" and "A2" in analogy to the macrophage nomenclature [243]. Interestingly, $\mathrm{S}_{1} \mathrm{P}_{3}$ was induced 46 -fold after MCAO but only 6.4 -fold by LPS. Under physiological circumstances, astrocytes were reported to express mainly $\mathrm{S}_{1} \mathrm{P}_{1}$ and $\mathrm{S}_{1} \mathrm{P}_{3}$, contrasting with very low levels for $\mathrm{S}_{1} \mathrm{P}_{2}$ and $\mathrm{S1P}_{5}$ [244-246]. However, in a recent study by Karunakaran et al., the authors demonstrated the importance of $\mathrm{S}_{2} \mathrm{P}_{2}$ in microglial activation conferring impaired autophagy and propagating the inflammatory response in the BV2 microglial cell line [247]. Interestingly, similar effects were observed by the group after exogenous S1P administration or genetic knock out of SGPL1 [247].

S1P signaling is also functionally linked to influencing the pathophysiology during subarachnoid hemorrhage (SAH). In accordance with the detrimental effects caused by $\mathrm{S}_{2} \mathrm{P}_{2}$ ligation in ischemia-reperfusion mentioned before, Yagi et al., demonstrated that S1P signaling increases vascular tone in the context of SAH, thus worsening neurological scores [248]. By employing a selective

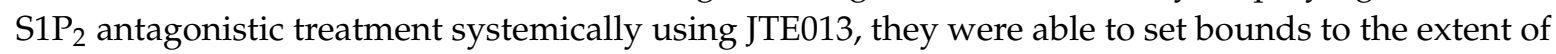
myogenic reactivity and to restore neurological scores to sham levels when administered instantly after SAH induction [248].

The various conditions that perturbed S1P signaling has been linked with are summed up in Figure 3.

\section{Insights into Current and Future Therapeutic Perspectives}

Almost a decade ago, the FDA approved the first drug aimed to interfere with the S1P-S1PR signaling cascade, fingolimod, in 2010 [162]. Due to fingolimod's preference for $\mathrm{S}_{1} \mathrm{P}_{1}$ and the strong activation of this receptor subtype, $\mathrm{S}_{1} \mathrm{P}_{1}$ eventually becomes down-regulated, resulting in a long-lasting functional antagonism that accounts for fingolimod-induced lymphocyte trapping in primary and secondary lymphoid organs. Consequently, this lymphocyte sequestration prevents auto-reactive $\mathrm{T}$ cells to migrate to the brain and therefore reduces the ferocious neurotoxic damage to myelin-associated 
proteins in patients with multiple sclerosis $[158,249]$. Nevertheless, due to its lack of specificity, a range of adverse effects (e.g., first-dose bradycardia [250], macular edema [251], elevated liver enzymes [252], and lymphopenia warranting vigilance regarding occurrence of infections [253-255]) is inevitable [256]. The endeavor to circumvent these unwanted drug effects led to the development of more tailored drugs aimed at selectively activating or inhibiting checkpoints within the sphingolipid metabolism on demand. To date, there is a huge number of clinical trials either completed (C), terminated (T), or momentarily being conducted in various clinical conditions examining the pharmacological exploitability of drugs designed to beneficially influence targets within the sphingolipid metabolism. A selection of these studies is presented below (Table 1). It is advisable to conceive that potentially all molecules/agents addressed in Figures 1 and 2 may represent future therapeutic targets.

Safingol, which targets PKC and non-selectively sphingosine kinases (SphK) [257], was identified in 1995 [258]. Safingol is now being tested in various cancer settings, since it is safe to co-administer with cisplatin and exerts tumoricidal effects $[259,260]$. Similarly, another drug targets SphK. The compound 3-(4-chlorophenyl)-adamantane-1-carboxylic acid (pyridine-4-ylmethyl)amide (ABC294-640) selectively inhibits SphK2. ABC294640 was identified in 2010 [261] and mechanistically competes with sphingosine for binding sites at SphK2. This, in turn, allows sphingosine and ceramides levels to increase (due to inability/slower rate of enzymatical conversion to S1P), facilitating apoptosis-inducing pathways $[2,6,262]$ - a mechanism that was recently studied in various cancer therapies [263-266]. In that regard, conceivably, the exploitation of PKC and SphK subtypes in neurological conditions where their homeostasis of molecular activation, proliferation, and apoptosis is perturbed by crucially diminishing the S1P level within a cell and its immediate effects via PKC appears intuitive. This remains apprehensible, since S1P levels were previously shown to be enhanced to the disadvantage of its pro-differentiative and pro-apoptotic precursor ceramide $[267,268]$.

Previously, a S1P-directed therapeutic agent was introduced [269]. The S1P-specific monoclonal antibody sonepcizumab (LT1009) is being tested in conditions where pathologies of the vasculature system occur [270-272]. 
Table 1. Trials of drugs interfering with the sphingosine 1-phosphate metabolism in clinical conditions. (C), completed; (T), terminated; (S), suspended (one study currently on halt due to COVID-19-related recruitment stop); SPHK1/2, sphingosine kinase 1/2; PKC, protein kinase C; S1P, sphingosine 1-phosphate; S1P $\mathrm{n}$, S1P receptor ' $n$ '.

\begin{tabular}{|c|c|c|c|c|}
\hline Target & Compounds (Mechanism of Action) & Indications & ClinicalTrials.gov Identifier & Phase \\
\hline \multirow{2}{*}{ SPHK1/2, PKC inhibitor } & \multirow{2}{*}{ Safingol } & Solid tumor & NCT01553071 & I \\
\hline & & Adult solid tumor (unspec.) & NCT00084812 & $\mathrm{I}(\mathrm{C})$ \\
\hline \multirow{4}{*}{ SPHK2 } & \multirow{4}{*}{$\begin{array}{c}\text { ABC294640 } \\
\text { (SPHK2 inhibition) }\end{array}$} & \multirow{2}{*}{ Non-resectable, perihilar cholangiocarcinoma (extra- and intrahepatic) } & NCT03377179 & II \\
\hline & & & NCT03414489 & $\mathrm{n} / \mathrm{a}$ \\
\hline & & Pancreatic cancer, adult solid tumor (unspec.) & NCT01488513 & $\mathrm{I}(\mathrm{C})$ \\
\hline & & Multiple myeloma & NCT02757326 & $\mathrm{I}, \mathrm{II}(\mathrm{T})$ \\
\hline \multirow{9}{*}{ S1P } & \multirow{4}{*}{$\mathrm{n} / \mathrm{a}$} & Bacterial pneumonia & NCT04007328 & II, III \\
\hline & & Food Allergy, anaphylaxis & NCT01776489 & $\mathrm{n} / \mathrm{a}$ \\
\hline & & Asthma & NCT04134351 & $\mathrm{n} / \mathrm{a}$ \\
\hline & & Pneumonia, chronic obstructive pulmonary disease, asthma & NCT03473119 & $\mathrm{n} / \mathrm{a}$ \\
\hline & \multirow{5}{*}{$\begin{array}{l}\text { Sonepcizumab [LT1009] } \\
\text { (S1P-specific mAb) }\end{array}$} & Solid tumors & NCT00661414 & $\mathrm{I}(\mathrm{C})$ \\
\hline & & Neovascular age-related macular degeneration & NCT00767949 & I \\
\hline & & Exudative age-related macular degeneration & NCT01414153 & II (C) \\
\hline & & Pigment epithelial detachment & NCT01334255 & $\mathrm{I}(\mathrm{T})$ \\
\hline & & Renal cell carcinoma & NCT01762033 & II (T) \\
\hline \multirow{2}{*}{ S1P lyase } & \multirow{2}{*}{$\begin{array}{c}\text { LX3305 } \\
\text { (S1P lyase inhibition) }\end{array}$} & \multirow{2}{*}{ Rheumatoid arthritis } & $\begin{array}{l}\text { NCT00847886, } \\
\text { NCT01417052 }\end{array}$ & $\mathrm{I}(\mathrm{C})$ \\
\hline & & & NCT00903383 & II (C) \\
\hline
\end{tabular}


Table 1. Cont.

\begin{tabular}{|c|c|c|c|c|}
\hline Target & Compounds (Mechanism of Action) & Indications & ClinicalTrials.gov Identifier & Phase \\
\hline \multirow{25}{*}{$\mathrm{S}_{1} \mathrm{P}_{1}$} & \multirow{3}{*}{$\mathrm{n} / \mathrm{a}$} & Interstitial cystitis & NCT03003845 & $\mathrm{n} / \mathrm{a}$ \\
\hline & & Endometriosis & NCT02973854 & $\mathrm{n} / \mathrm{a}$ \\
\hline & & Vulvodynia & NCT02981433 & $\mathrm{n} / \mathrm{a}$ \\
\hline & \multirow{2}{*}{ AKP11 } & Atopic dermatitis & ACTRN12617000763347 & II \\
\hline & & Rheumatoid arthritis & ACTRN12617001223325 & II \\
\hline & BMS-986104 & Rheumatoid arthritis (healthy volunteers) & NCT02211469 & II (C) \\
\hline & \multirow{3}{*}{$\begin{array}{l}\text { Cenerimod }[\mathrm{ACT}-334441] \\
\left(\mathrm{S}_{1} \mathrm{P}_{1} \text { agonist }\right)\end{array}$} & Systemic lupus erythematosus & NCT02472795 & I, II (C) \\
\hline & & \multirow{2}{*}{ Healthy volunteers } & NCT04052360 & $\mathrm{I}(\mathrm{C})$ \\
\hline & & & NCT04255277 & I \\
\hline & $\begin{array}{c}\text { CS-077 } \\
\text { (S1P } 1 \text { agonist) }\end{array}$ & Multiple sclerosis & NCT00616733 & $\mathrm{I}(\mathrm{C})$ \\
\hline & \multirow{2}{*}{$\begin{array}{l}\text { GSK2018682 } \\
\text { (S1P } 1 \text { agonist) }\end{array}$} & $\begin{array}{l}\text { Multiple sclerosis } \\
\text { (healthy volunteers) }\end{array}$ & NCT01387217 & $\mathrm{I}(\mathrm{C})$ \\
\hline & & $\begin{array}{l}\text { Relapsing-remitting multiple sclerosis } \\
\text { (healthy volunteers) }\end{array}$ & $\begin{array}{l}\text { NCT01466322, } \\
\text { NCT01431937 }\end{array}$ & $\mathrm{I}(\mathrm{C})$ \\
\hline & \multirow{3}{*}{$\begin{array}{c}\mathrm{KRP} 203 \\
\left(\mathrm{~S} 1 \mathrm{P}_{1} \text { agonist }\right)\end{array}$} & Subacute cutaneous lupus erythematosus & NCT01294774 & II (C) \\
\hline & & Hematological malignancies & NCT01830010 & $\mathrm{I}(\mathrm{C})$ \\
\hline & & Ulcerative colitis & NCT01375179 & II (T) \\
\hline & \multirow{10}{*}{ 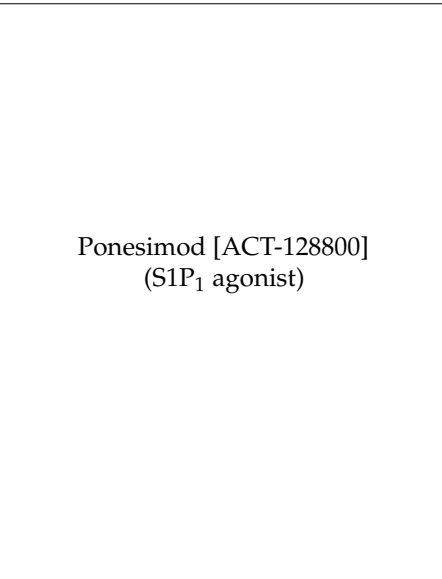 } & \multirow{3}{*}{ Multiple sclerosis } & NCT02425644 & III (C) \\
\hline & & & NCT03232073 & III \\
\hline & & & NCT02907177 & III (T) \\
\hline & & \multirow{2}{*}{ Relapsing-remitting multiple sclerosis } & NCT01093326 & II \\
\hline & & & NCT01006265 & II (C) \\
\hline & & Plaque psoriasis & $\begin{array}{l}\text { NCT00852670, } \\
\text { NCT01208090 }\end{array}$ & II (C) \\
\hline & & Chronic graft versus host disease & NCT02461134 & II (T) \\
\hline & & Healthy volunteers & $\begin{array}{l}\text { NCT02136888, } \\
\text { NCT02068235, } \\
\text { NCT03882255, } \\
\text { NCT02223832 }\end{array}$ & $\mathrm{I}(\mathrm{C})$ \\
\hline & & Pharmacokinetics & NCT02126956 & $\mathrm{I}(\mathrm{C})$ \\
\hline & & Safety and tolerability & NCT02029482 & $\mathrm{I}(\mathrm{C})$ \\
\hline
\end{tabular}


Table 1. Cont.

\begin{tabular}{|c|c|c|c|c|}
\hline Target & Compounds (Mechanism of Action) & Indications & ClinicalTrials.gov Identifier & Phase \\
\hline \multirow{12}{*}{ 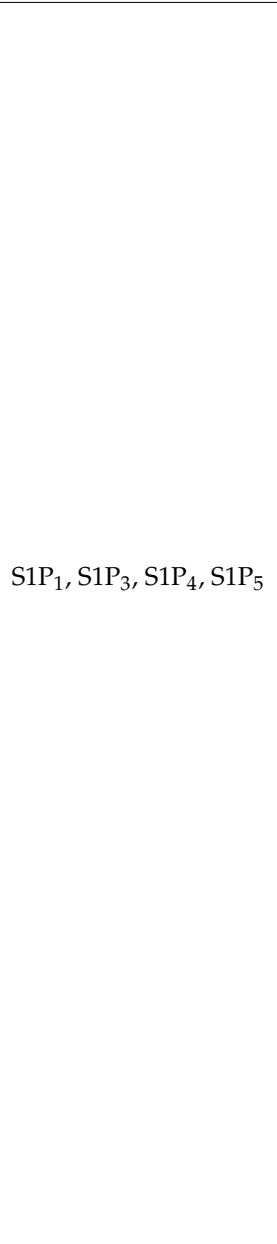 } & \multirow{12}{*}{$\begin{array}{c}\text { Fingolimod [FTY720] } \\
\text { (S1PR modulator, } \mathrm{S}_{1} \mathrm{P}_{1} \text { functional } \\
\text { antagonist) }\end{array}$} & Healthy volunteers & $\begin{array}{l}\text { NCT00416845, } \\
\text { NCT03757338 }\end{array}$ & $\mathrm{I}(\mathrm{C})$ \\
\hline & & \multirow{7}{*}{ Multiple sclerosis } & $\begin{array}{l}\text { NCT00537082, } \\
\text { NCT00670449, } \\
\text { NCT00333138 }\end{array}$ & II (C) \\
\hline & & & NCT01892722 & III \\
\hline & & & $\begin{array}{l}\text { NCT00662649, } \\
\text { NCT00355134, } \\
\text { NCT02939079, } \\
\text { NCT00340834 }\end{array}$ & III (C) \\
\hline & & & NCT01647880 & III (T) \\
\hline & & & $\begin{array}{l}\text { NCT01585298, } \\
\text { NCT01333501 }\end{array}$ & IV (C) \\
\hline & & & $\begin{array}{l}\text { NCT02232061, } \\
\text { NCT01981161, } \\
\text { NCT02769689 }\end{array}$ & IV \\
\hline & & & $\begin{array}{l}\text { NCT02139696, } \\
\text { NCT01592097, } \\
\text { NCT01285479, } \\
\text { NCT01281657, } \\
\text { NCT02225977, } \\
\text { NCT02408380, } \\
\text { NCT03216915, } \\
\text { NCT01811290, } \\
\text { NCT02799199, } \\
\text { NCT02776072, } \\
\text { NCT01442194, } \\
\text { NCT02021162, } \\
\text { NCT02307877, } \\
\text { NCT03243721 }\end{array}$ & $\mathrm{n} / \mathrm{a}$ \\
\hline & & Multiple sclerosis (autonomic nervous system dysfunction) & NCT02048072 & IV (C) \\
\hline & & Multiple sclerosis (fatigue) & NCT01490840 & IV (T) \\
\hline & & Multiple sclerosis (cognitive deficits) & NCT02141022 & $\mathrm{n} / \mathrm{a}$ \\
\hline & & Primary progressive multiple sclerosis & NCT00731692 & III (T) \\
\hline
\end{tabular}


Table 1. Cont.

\begin{tabular}{|c|c|c|c|c|}
\hline Target & Compounds (Mechanism of Action) & Indications & ClinicalTrials.gov Identifier & Phase \\
\hline \multirow{12}{*}{ 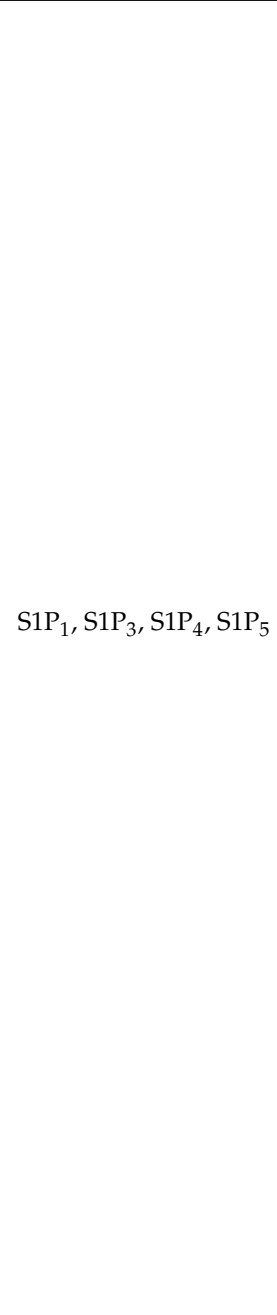 } & \multirow{12}{*}{$\begin{array}{l}\text { Fingolimod [FTY720] } \\
\text { (S1PR modulator, } \mathrm{S}_{1} \\
\text { functional antagonist) }\end{array}$} & \multirow{5}{*}{ Relapsing-remitting multiple sclerosis } & $\begin{array}{l}\text { NCT00289978, } \\
\text { NCT01127750, } \\
\text { NCT01201356, } \\
\text { NCT01497262, } \\
\text { NCT01199861 }\end{array}$ & III (C) \\
\hline & & & $\begin{array}{l}\text { NCT01499667, } \\
\text { NCT01633112 }\end{array}$ & III (T) \\
\hline & & & $\begin{array}{l}\text { NCT01310166, } \\
\text { NCT02325440 }\end{array}$ & IV \\
\hline & & & $\begin{array}{l}\text { NCT01755871, } \\
\text { NCT02342704, } \\
\text { NCT03345940 }\end{array}$ & IV (T) \\
\hline & & & $\begin{array}{l}\text { NCT01790269, } \\
\text { NCT01704183, } \\
\text { NCT02335892, } \\
\text { NCT02277964 }\end{array}$ & $\mathrm{n} / \mathrm{a}$ \\
\hline & & Relapsing-remitting multiple sclerosis (cognition, brain volume loss) & NCT02575365 & IV (T) \\
\hline & & Relapsing-remitting multiple sclerosis (depression) & NCT01436643 & IV (T) \\
\hline & & Acute demyelinating optic neuritis & NCT01757691 & $\mathrm{II}(\mathrm{T})$ \\
\hline & & Amyotrophic lateral sclerosis & NCT01786174 & $\mathrm{II}(\mathrm{C})$ \\
\hline & & Intracerebral hemorrhage (hypertensive, intraparenchymal), cerebral edema & NCT04088630 & I \\
\hline & & (Acute) stroke, (cerebro-) vascular accident, cerebral stroke & NCT02002390 & II (C) \\
\hline & & Chemotherapy-induced peripheral neuropathy (numbness, pain, tingling) & NCT03943498 & I \\
\hline
\end{tabular}


Table 1. Cont.

\begin{tabular}{|c|c|c|c|c|}
\hline Target & Compounds (Mechanism of Action) & Indications & ClinicalTrials.gov Identifier & Phase \\
\hline \multirow{9}{*}{$\mathrm{S}_{1} \mathrm{P}_{1}, \mathrm{~S}_{1} \mathrm{P}_{3}, \mathrm{~S}_{1} \mathrm{P}_{4}, \mathrm{~S}_{1} \mathrm{P}_{5}$} & \multirow{9}{*}{$\begin{array}{c}\text { Fingolimod [FTY720] } \\
\text { (S1PR modulator, } \mathrm{S}_{1} \mathrm{P}_{1} \text { functional } \\
\text { antagonist) }\end{array}$} & Chronic inflammatory demyelinating polyradiculoneuropathy & NCT01625182 & III (C) \\
\hline & & Breast carcinoma & NCT03941743 & I \\
\hline & & Glioblastoma, anaplastic astrocytoma & NCT02490930 & $\mathrm{I}(\mathrm{C})$ \\
\hline & & Coronavirus disease (COVID-19) & NCT04280588 & II \\
\hline & & Asthma & NCT00785083 & $\mathrm{II}(\mathrm{C})$ \\
\hline & & Rett syndrome & NCT02061137 & II (C) \\
\hline & & Schizophrenia & NCT01779700 & II (C) \\
\hline & & \multirow[b]{2}{*}{ Kidney transplantation } & $\begin{array}{l}\text { NCT00239902, } \\
\text { NCT00239798 }\end{array}$ & II (C) \\
\hline & & & $\begin{array}{l}\text { NCT00099736, } \\
\text { NCT00239876, } \\
\text { NCT00239811, } \\
\text { NCT00099801, } \\
\text { NCT00099749, } \\
\text { NCT00239863, } \\
\text { NCT00239785, } \\
\text { NCT00098735 }\end{array}$ & III (C) \\
\hline \multirow{7}{*}{$\mathrm{S}_{1} \mathrm{P}_{1}, \mathrm{~S}_{1} \mathrm{P}_{5}$} & $\begin{array}{l}\text { Ceralifimod [ONO-4641] } \\
\quad\left(\mathrm{S}_{1} \mathrm{P}_{1,5} \text { agonist }\right)\end{array}$ & Multiple sclerosis & NCT01226745 & $\mathrm{II}(\mathrm{T})$ \\
\hline & \multirow{6}{*}{$\begin{array}{l}\text { Ozanimod [RPC1063] } \\
\text { (S1P } \mathrm{P}_{1,5} \text { agonist) }\end{array}$} & \multirow{3}{*}{ Multiple sclerosis } & NCT02797015 & $\mathrm{I}(\mathrm{C})$ \\
\hline & & & $\begin{array}{l}\text { NCT02576717, } \\
\text { NCT04140305 }\end{array}$ & III \\
\hline & & & NCT02294058 & III (C) \\
\hline & & Relapsing-remitting multiple sclerosis & $\begin{array}{l}\text { NCT01628393, } \\
\text { NCT02047734 }\end{array}$ & III (C) \\
\hline & & \multirow[b]{2}{*}{ Ulcerative colitis } & NCT01647516 & II \\
\hline & & & $\begin{array}{l}\text { NCT02435992, } \\
\text { NCT02531126, } \\
\text { NCT03915769 }\end{array}$ & III \\
\hline
\end{tabular}


Table 1. Cont

\begin{tabular}{|c|c|c|c|c|}
\hline Target & Compounds (Mechanism of Action) & Indications & ClinicalTrials.gov Identifier & Phase \\
\hline \multirow{12}{*}{$\mathrm{S}_{1} \mathrm{P}_{1},{\mathrm{~S} 1 \mathrm{P}_{5}}$} & \multirow{4}{*}{$\begin{array}{l}\text { Ozanimod [RPC1063] } \\
\quad\left(\mathrm{S}_{1} \mathrm{P}_{1,5} \text { agonist }\right)\end{array}$} & \multirow[b]{2}{*}{ Crohn's disease } & NCT02531113 & II (C) \\
\hline & & & $\begin{array}{l}\text { NCT03467958, } \\
\text { NCT03464097, } \\
\text { NCT03440372, } \\
\text { NCT03440385 }\end{array}$ & III \\
\hline & & \multirow[t]{2}{*}{ Healthy volunteers } & $\begin{array}{l}\text { NCT02994381, } \\
\text { NCT03694119, } \\
\text { NCT03644576, } \\
\text { NCT03624959, } \\
\text { NCT03665610 }\end{array}$ & $\mathrm{I}(\mathrm{C})$ \\
\hline & & & $\begin{array}{l}\text { NCT04149678, } \\
\text { NCT04211558 }\end{array}$ & I \\
\hline & \multirow{8}{*}{$\begin{array}{l}\text { Siponimod [BAF312] } \\
\text { (S1P }_{1,5} \text { modulator) }\end{array}$} & Healthy volunteers & NCT00422175 & $\mathrm{I}(\mathrm{C})$ \\
\hline & & Multiple sclerosis & NCT03623243 & III \\
\hline & & Relapsing-remitting multiple sclerosis & $\begin{array}{l}\text { NCT01185821, } \\
\text { NCT00879658 }\end{array}$ & II (C) \\
\hline & & \multirow{2}{*}{ Secondary progressive multiple sclerosis } & NCT01665144 & III \\
\hline & & & NCT02330965 & $\mathrm{n} / \mathrm{a}$ \\
\hline & & Hepatic impairment & NCT01565902 & $\mathrm{I}(\mathrm{C})$ \\
\hline & & Hemorrhagic stroke, intracerebral hemorrhage (ICH) & NCT03338998 & II (S) \\
\hline & & Renal impairment & NCT01904214 & $\mathrm{I}(\mathrm{C})$ \\
\hline
\end{tabular}


Table 1. Cont.

\begin{tabular}{|c|c|c|c|c|}
\hline Target & Compounds (Mechanism of Action) & Indications & ClinicalTrials.gov Identifier & Phase \\
\hline \multirow{14}{*}{$\mathrm{S}_{1} \mathrm{P}_{1}, \mathrm{~S}_{1} \mathrm{P}_{5},\left(\mathrm{~S}_{1} \mathrm{P}_{4}\right)$} & \multirow{7}{*}{$\begin{array}{l}\text { Amiselimod [MT-1303] } \\
\text { (S1PR modulator, } \mathrm{S}_{1} \mathrm{P}_{1} \\
\text { functional antagonist) }\end{array}$} & Relapsing-remitting multiple sclerosis & $\begin{array}{l}\text { NCT02193217, } \\
\text { NCT02310048, } \\
\text { NCT02293967 }\end{array}$ & $\mathrm{I}(\mathrm{C})$ \\
\hline & & & $\begin{array}{l}\text { NCT01890655, } \\
\text { NCT01742052 }\end{array}$ & II (C) \\
\hline & & \multirow[b]{2}{*}{ Crohn's disease } & NCT02148185 & $\mathrm{I}(\mathrm{C})$ \\
\hline & & & $\begin{array}{l}\text { NCT02389790, } \\
\text { NCT02378688 }\end{array}$ & II (C) \\
\hline & & Systemic lupus erythematosus & NCT02307643 & $\mathrm{I}(\mathrm{C})$ \\
\hline & & Plaque psoriasis & NCT01987843 & $\mathrm{II}(\mathrm{C})$ \\
\hline & & Inflammatory bowel disease & NCT01666327 & $\mathrm{I}(\mathrm{C})$ \\
\hline & \multirow{7}{*}{ Etrasimod [APD334] } & Primary biliary cholangitis & NCT03155932 & $\mathrm{II}(\mathrm{T})$ \\
\hline & & Inflammatory bowel disease(extra-int. skin manifestations) & NCT03139032 & II (T) \\
\hline & & \multirow[b]{2}{*}{ Ulcerative colitis } & $\begin{array}{l}\text { NCT02447302, } \\
\text { NCT02536404 }\end{array}$ & II (C) \\
\hline & & & $\begin{array}{l}\text { NCT03950232, } \\
\text { NCT03945188, } \\
\text { NCT03996369, } \\
\text { NCT04176588 }\end{array}$ & III \\
\hline & & Pyoderma gangrenosum & NCT03072953 & $\mathrm{II}(\mathrm{T})$ \\
\hline & & Crohn's disease & NCT04173273 & II \\
\hline & & Atopic dermatitis & NCT04162769 & II \\
\hline
\end{tabular}


Conversely to the aforementioned mechanisms inevitably reducing the amount of S1P available, drugs either mimicking S1P effects at the receptor site or actually increasing S1P levels have been designed. The S1P lyase inhibitor LX3305 is currently being investigated in rheumatoid arthritis as an alternative to therapies with biologicals [273]. Conceptually, LX3305's tentative application in neurological conditions where S1P is reduced/disturbed appears undoubtedly apprehensible, e.g., in neurodegenerative disorders such as Alzheimer's disease [134], Parkinson's disease [274], Huntington's disease [151,153], or amyotrophic lateral sclerosis [154]. Several diseases have been implicated in aberrant S1PR-specific signaling pathways. In that regard, several drugs specifically designed to interact with $\mathrm{S}_{1} \mathrm{P}_{1}$ are available to date. AKP11, for example, was compared against fingolimod in a rodent model of multiple sclerosis and was associated with a higher degree of endosomal receptor recycling upon withdrawal, lesser extent of proteasomal degradation, and milder and more easily reversible lymphopenia [275]. Despite similar therapeutic effects, an almost complete absence of adverse events was observed [275]. Similarly, but more recently, BMS-986104 was shown to act equivalently efficient to fingolimod in a T cell transfer colitis model, although not conveying as many cardiovascular and pulmonary adverse events in in vitro settings [276]. Moreover, cenerimod (ACT-334441) could also be confirmed as a potent and selective S1P $_{1}$ agonistic signaling properties, whilst broncho- and vasoconstrictive effects were not clinically relevant [277]. In humans, cenerimod showed an improvement in disease activity scores for systemic lupus without constraining an acceptable safety profile [278]. In contrast to these specific and well-tolerable agents, GSK2018682, another $\mathrm{S}_{1} \mathrm{P}_{1}$ agonist, did bring about bradycardia and subsequent AV-block [279]. In contrast, BMS-986104 and cenerimod seem to have a favorable risk profile in comparison to fingolimod, which, of course, warrants further investigation in in vivo studies to determine its safety and efficacy in other conditions. Interestingly, in pancreatic islet transplantation, which at least in humans is a definitive treatment for type 1 diabetes mellitus denoted by high mortality and morbidity in the early phase after transplantation [280], KRP203 was shown to cause a marked increase in viable pancreatic islet transplants in C57BL/10 mice [281]. Nevertheless, KRP203 is not an entirely selective $\mathrm{S1P}_{1}$ agonist, as it does bind to $\mathrm{S}_{1} \mathrm{P}_{3}$ with 5 -fold and to $\mathrm{S}_{2} \mathrm{P}_{2}$ and $\mathrm{S}_{1} \mathrm{P}_{5}$ 100-fold lesser selectivity [281]. Thus, concerns regarding adverse effects, particularly with potentially increased doses necessary and depending on pharmacogenetics, should govern careful investigations in humans. Lastly with respect to $\mathrm{S}_{1} \mathrm{P}_{1}$ specific compounds, ponesimod (ACT-128800) was previously reported to display therapeutic efficacy in psoriasis whilst also distinguishing itself by swift reversibility upon discontinuation; however, some degree of cardiac effects was detected in clinical trials [282].

It may be advised, under some conditions, to exploit multiple S1PR pathways. $\mathrm{S}^{\mathrm{P}} \mathrm{P}_{5}$, for example, is implicated in having pro-fibrotic effects to act on proliferation and its involvement in early transforming-growth-factor- $\beta$ (TGF- $\beta$ )-signaling [283]. Therefore, fibrotic conditions or tissue scarring might be well-suited for treatment with an agent synthesized to evoke agonistic effects both against $\mathrm{S}_{1} \mathrm{P}_{1}$ and $\mathrm{S}_{1} \mathrm{P}_{5}$. Three compounds are currently being tested, which act in this pharmacological manner, namely: ceralifimod (ONO-4641), ozanimod (RPC1063), and siponimod (BAF312).

Ceralifimod (ONO-4641), 1-((6-(2-methoxy-4-propylbenzyl)oxy)-1-methyl-3,4-dihydronaphthalen -2-yl)methyl)azetidine-3-carboxylic acid 13n was recently synthesized in 2017 [284]. Beside ceralifimod, ozanimod (RPC1063), which acts similarly, was shown to cause beneficial effects in patients with multiple sclerosis and ulcerative colitis alike [285]. In addition, the authors found that ozanimod wielded strong influence on the innate immune cells. Here, plasmacytoid dendritic cells were lowered (potentially by means of sequestration), which, in turn, reduced interferon alpha (IFN- $\alpha$ ) in lupus patients in addition to reducing the entirety of $\mathrm{B}$ cell and $\mathrm{T}$ cell subsets in the spleen [285].

Lastly, agents that not only depicted $\mathrm{S}_{1} \mathrm{P}_{1}$ and $\mathrm{S}_{1} \mathrm{P}_{5}$ agonistic features but that also were partially able to engage with $\mathrm{S}_{4} \mathrm{P}_{4}$ were identified. This cohort of compounds currently comprises amiselimod (MT-1303) and etrasimod (APD334). The potential of being able to engage with $\mathrm{S1P}_{4}$ may hold promising therapeutic benefits. In this regard, $\mathrm{S} \mathrm{P}_{4}$, as discussed previously in this review, is predominantly expressed in lymphoid tissues [88,95], and ligation and its subsequent signaling are involved in 
marking time regarding proliferation [286,287], a reduction of effector cytokines secreted [286,287], and migration of lymphocytes [288,289]. It is worth noting that amiselimod displays a very safe risk profile [290-292], while it is too early to consistently assess this for etrasimod [293]. Their application and/or investigation regarding their future therapeutic exploitability in neurological conditions should find due consideration soon.

\section{Conclusions}

In this review, we described the complexities of the sphingosine 1-phosphate (S1P) signaling in neurological conditions in reflection of currently available S1P signaling targeted drugs. Starting with the de novo synthesis of S1P either at the smooth endoplasmic reticulum or other subcellular microdomains, we highlighted the currently established signaling pathways. However, S1P signaling also occurs after secretion and transportation by its chaperones HDL or albumin in the extracellular compartment, allowing either autocrine or paracrine signaling upon ligation to $\mathrm{S}_{1} \mathrm{P}_{1-5}$. It was highlighted that each S1PR subtype is capable of coupling to a variety of heterotrimeric G proteins, subsequently allowing a tailored intracellular signaling cascade to be incited. However, under perturbed circumstances, the presence of co-activators, inhibitors of S1PR, or simply skewed S1PR patterns may predispose for disease onset and progression. Despite remarkable advances in understanding the contribution of sphingolipid signaling to neurological disorders, the field has yet a lot to learn. In this review, we highlighted the currently available literature regarding perturbations of the sphingolipid metabolism in the context of neurodegenerative, neuroinflammatory, and cerebrovascular diseases. A considerable number of clinical trials are being carried out testing S1P signaling targeted drugs in conditions linked to activation of the immune system. These trials may enhance our understanding of the importance of the S1P-S1PR axis and ultimately help to inform us about future therapeutic usability of these compounds in various neurological disorders. We reported on the importance of $\mathrm{S} \mathrm{P}_{1}$ for vascular and other barrier functions. Activation of $\mathrm{S} \mathrm{P}_{1}$ causes a significant improvement of vascular barrier properties and prevents microvascular leakage. Currently available drugs interacting with $\mathrm{S}_{1} \mathrm{P}_{1}$ initially act as agonists but then may cause a profound and long-lasting desensitization and degradation of $\mathrm{S}_{1} \mathrm{P}_{1}$. As outlined above, they finally act as functional antagonists with, in the long term, negative impact on vascular integrity. Currently, there is no pure $\mathrm{S}_{1} \mathrm{P}_{1}$ receptor agonist available that does not desensitize the receptor. The compounds described thus far may indeed have a varying degree of agonistic and antagonistic properties. However, such a "true agonist" would be highly desirable and unique in order to protect from vascular leakage.

Author Contributions: A.L. and J.S. contributed equally to the design and the conception of this article and wrote the entire manuscript. R.B., J.M.P., and W.P. critically edited the manuscript and supervised the writing. All authors have read and agreed to the published version of the manuscript.

Funding: The authors would like to acknowledge the support by the Open Access Publication Fund of the Goethe University Frankfurt. R.B., J.M.P., and W.P. are funded by the German Research Organization (DFG; SFB1039). J.M.P. and W.P. are funded by the Fondation Leducq (SphingoNet). J.M.P. is funded by the Uniscientia Foundation Vaduz. J.S. is funded by a scholarship from the German Academic Scholarship Foundation (Studienstiftung des deutschen Volkes).

Conflicts of Interest: The authors declare no conflict of interest.

\section{Abbreviations}

$\begin{array}{ll}\text { AD } & \text { Alzheimer's disease } \\ \text { Akt } & \text { RAC-alpha serine/threonine-protein kinase } \\ \text { ALS } & \text { Amyotrophic lateral sclerosis } \\ \text { aPC } & \text { Activated protein C } \\ \text { ApoM } & \text { Apolipoprotein } M\end{array}$




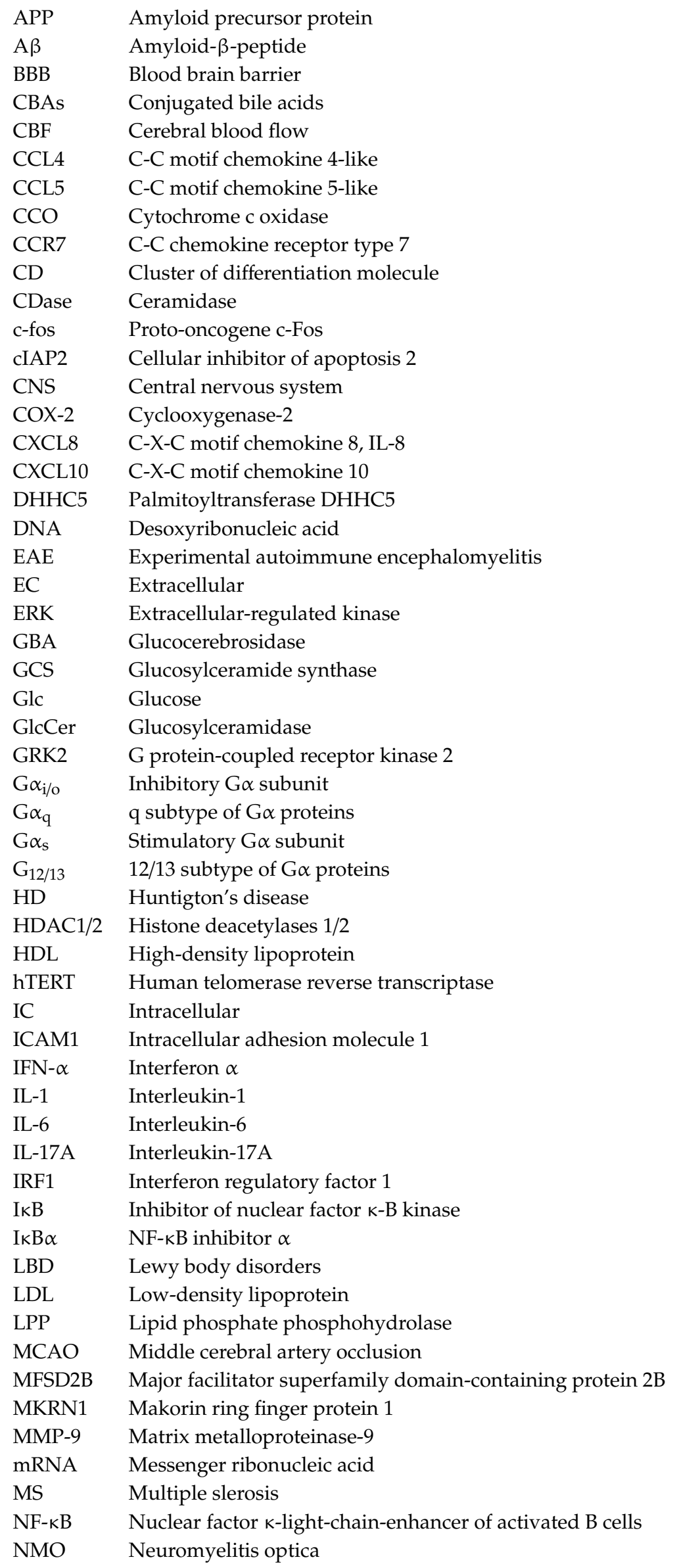




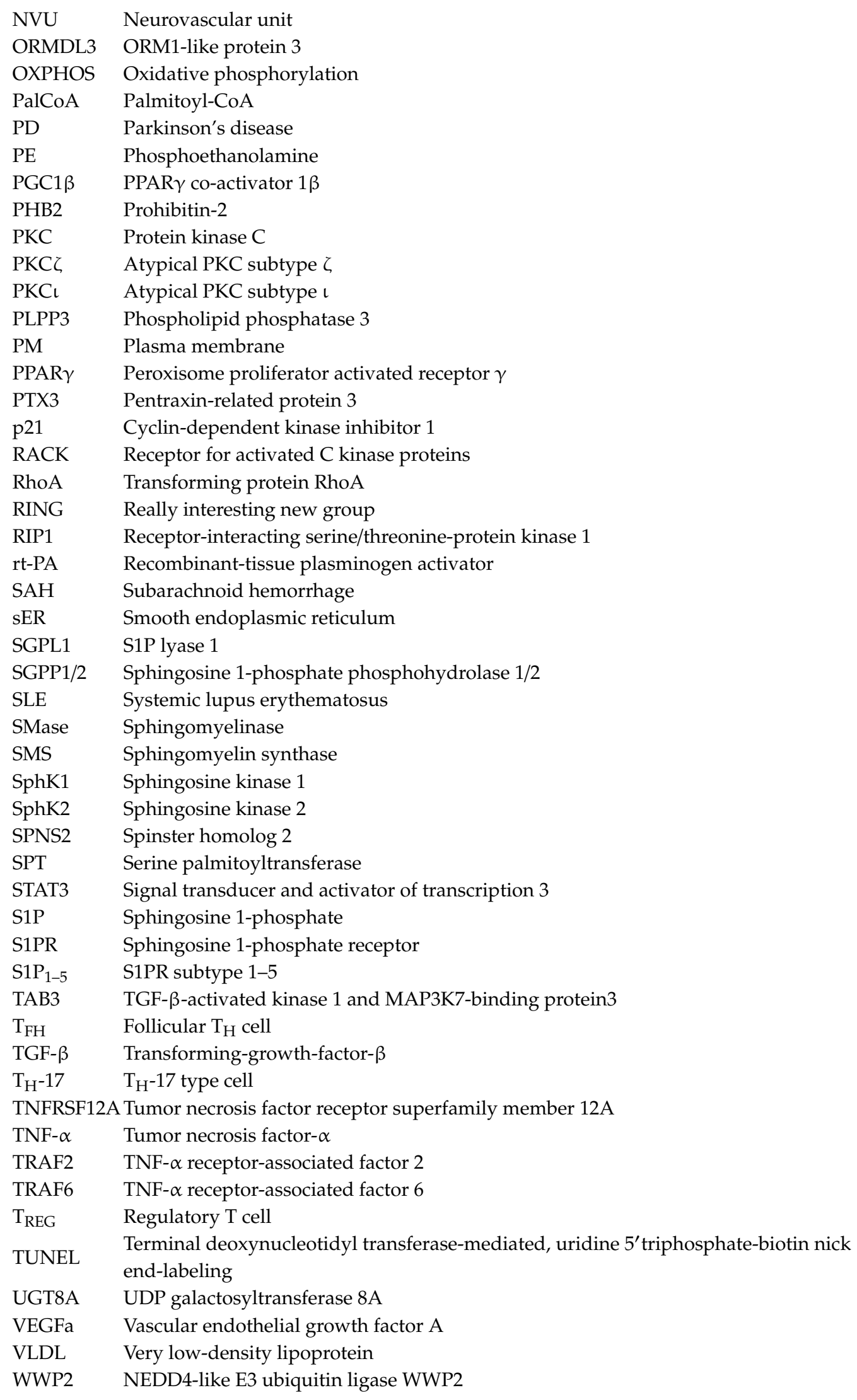




\section{References}

1. Zhang, H.; Desai, N.N.; Olivera, A.; Seki, T.; Brooker, G.; Spiegel, S. Sphingosine-1-phosphate, a novel lipid, involved in cellular proliferation. J. Cell Biol. 1991, 114, 155-167. [CrossRef]

2. Cuvillier, O.; Pirianov, G.; Kleuser, B.; Vanek, P.G.; Coso, O.A.; Gutkind, S.; Spiegel, S. Suppression of cermide-mediated programmed cell death by sphingosine-1-phosphate. Nature 1996, 381, 800-803. [CrossRef]

3. Breslow, D.K.; Collins, S.R.; Bodenmiller, B.; Aebersold, R.; Simons, K.; Shevchenko, A.; Ejsing, C.S.; Weissman, J.S. Orm family proteins mediate sphingolipid homeostasis. Nature 2010, 463, 1048-1053. [CrossRef] [PubMed]

4. Breslow, D.K.; Weissman, J.S. Membranes in Balance: Mechanisms of Sphingolipid Homeostasis. Mol. Cell. 2010, 40, 267-279. [CrossRef] [PubMed]

5. Hannun, Y.A.; Obeid, L.M. The ceramide-centric universe of lipid-mediated cell regulation: Stress encounters of the lipid kind. J. Biol. Chem. 2002, 277, 25847-25850. [CrossRef]

6. Linn, S.C.; Kim, H.S.; Keane, E.M.; Andras, L.M.; Wang, E.; Merrill, A.H., Jr. Regulation of de novo sphingolipid biosynthesis and the toxic consequences of its disruption. Biochem. Soc. Trans. 2001, 29, 831-835. [CrossRef]

7. Xu, R.; Jin, J.; Hu, W.; Sun, W.; Bielawski, J.; Szulc, Z.; Taha, T.; Obeid, L.M.; Mao, C. Golgi alkaline ceramidase regulates cell proliferation and survival by controlling levels of sphingosine and S1P. FASEB J. 2006, 20, 1813-1825. [CrossRef] [PubMed]

8. Galadari, S.; Wu, B.X.; Mao, C.; Roddy, P.; El Bawab, S.; Hannun, Y.A. Identification of a novel amidase motif in neutral ceramidase. Biochem. J. 2006, 393, 687-695. [CrossRef] [PubMed]

9. Prinetti, A.; Loberto, N.; Chigorno, V.; Sonnino, S. Glycosphingolipid behaviour in complex membranes. Biochim. Biophys. Acta 2009, 1788, 184-193. [CrossRef]

10. Maceyka, M.; Spiegel, S. Sphingolipid metabolites in inflammatory disease. Nature 2014, 510, 58-67. [CrossRef]

11. Tafesse, F.G.; Ternes, P.; Holthuis, J.C.M. The multigenic sphingomyelin synthase family. J. Biol. Chem. 2006, 281, 29421-29425. [CrossRef] [PubMed]

12. Hakomori, S. Traveling for the glycosphingolipid path. Glycoconj. J. 2000, 17, 627-647. [CrossRef]

13. Ichikawa, S.; Hirabayashi, Y. Glucosylceramide synthase and glycosphingolipid synthesis. Trends Cell Biol. 1998, 8, 198-202. [CrossRef]

14. Zhou, J.; Saba, J.D. Identification of the first mammalian sphingosine phosphate lyase gene and its functional expression in yeast. Biochem. Biophys. Res. Commun. 1998, 242, 502-507. [CrossRef]

15. Bektas, M.; Allende, M.L.; Lee, B.G.; Chen, W.; Amar, M.J.; Remaley, A.T.; Saba, J.D.; Proia, R.L. Sphingosine 1-phosphate lyase deficiency disrupts lipid homeostasis in liver. J. Biol. Chem. 2010, 285, 10880-10889. [CrossRef] [PubMed]

16. Bandhuvula, P.; Saba, J.D. Sphingosine-1-phosphate lyase in immunity and cancer: Silencing the siren. Trends Mol. Med. 2007, 13, 210-217. [CrossRef]

17. Nakahara, K.; Ohkuni, A.; Kitamura, T.; Abe, K.; Naganuma, T.; Ohno, J.; Zoeller, R.A.; Kihara, A. The Sjögren-Larsson syndrome gene encodes a hexadecenal dehydrogenase of the sphingosine 1-phosphate degradation pathway. Mol. Cell. 2012, 46, 461-471. [CrossRef]

18. Dobrosotskaya, I.Y.; Seegmiller, A.C.; Brown, M.S.; Goldstein, J.L.; Rawson, R.B. Regulation of SREBP processing and membrane lipid production by phospholipids in Drosophila. Science 2002, 29, 879-883. [CrossRef] [PubMed]

19. Cantalupo, A.; Zhang, Y.; Kothiya, M.; Galvani, S.; Obinata, H.; Bucci, M.; Giordano, F.J.; Jiang, X.-C.; Hla, T.; Di Lorenzo, A. Nogo-B regulates endothelial sphingolipid homeostasis to control vascular function and blood pressure. Nat. Med. 2015, 21, 1028-1037. [CrossRef]

20. Zhang, Y.; Huang, Y.; Cantalupo, A.; Azevedo, P.S.; Siragusa, M.; Bielawski, J.; Giordano, F.J.; Di Lorenzo, A. Endothelial Nogo-B regulates sphingolipid biosynthesis to promote pathological cardiac hypertrophy during chronic pressure overload. JCI Insight 2016, 1, e85484. [CrossRef]

21. Le Stunff, H.; Giussani, P.; Maceyka, M.; Lépine, S.; Milstien, S.; Spiegel, S. Recycling of sphingosine is regulated by the concerted actions of sphingosine-1-phosphate phosphohydrolase 1 and sphingosine kinase 2 . J. Biol. Chem. 2007, 282, 34372-34380. [CrossRef] [PubMed] 
22. Ogawa, C.; Kihara, A.; Gokoh, M.; Igarashi, Y. Identification and characterization of a novel human sphingosine-1-phosphate phosphohydrolase, hSPP2. J. Biol. Chem. 2003, 278, 1268-1272. [CrossRef] [PubMed]

23. Kunkel, G.T.; Maceyka, M.; Milstien, S.; Spiegel, S. Targeting the sphingosine-1-phosphate axis in cancer, inflammation and beyond. Nat. Rev. Drug. Discov. 2013, 12, 688-702. [CrossRef] [PubMed]

24. Gillard, B.K.; Clement, R.G.; Marcus, D.M. Variations among cell lines in the synthesis of sphingolipids in de novo and recycling pathways. Glycobiology 1998, 8, 885-890. [CrossRef] [PubMed]

25. Tettamanti, G.; Bassi, R.; Viani, P.; Riboni, L. Salvage pathways in glycosphingolipid metabolism. Biochimie 2003, 85, 423-437. [CrossRef]

26. Cartier, A.; Hla, T. Sphingosine 1-phosphate: Lipid signaling in pathology and therapy. Science 2019, 366, eaar5551. [CrossRef]

27. Strub, G.M.; Paillard, M.; Liang, J.; Gomez, L.; Allegood, J.C.; Hait, N.C.; Maceyka, M.; Price, M.M.; Chen, Q.; Simpson, D.C; et al. Sphingosine-1-phosphate produced by sphingosine kinase 2 in mitochondria interacts with prohibitin 2 to regulate complex IV assembly and respiration. FASEB J. 2011, 25, 600-612. [CrossRef]

28. Maceyka, M.; Harikumar, K.B.; Milstien, S.; Spiegel, S. Sphingosine-1-phosphate signaling and its role in disease. Trends Cell Biol. 2012, 22, 50-60. [CrossRef]

29. Huwiler, A.; Kolter, T.; Pfeilschifter, J.; Sandhoff, K. Physiology and pathophysiology of sphingolipid metabolism and signaling. Biochim. Biophys. ACTA 2000, 1485, 63-99. [CrossRef]

30. Pappu, R.; Schwab, S.R.; Cornelissen, I.; Pereira, J.P.; Regard, J.B.; Xu, Y.; Camerer, E.; Zheng, Y.-W.; Huang, Y.; Cyster, J.G.; et al. Promotion of lymphocyte egress into blood and lymph by distinct sources of sphingosine-1-phosphate. Science 2007, 316, 295-298. [CrossRef]

31. Venkataraman, K.; Lee, Y.-M.; Michaud, J.; Thangada, S.; Ai, Y.; Bonkovsky, H.L.; Parikh, N.S.; Habrukowich, C.; Hla, T. Vascular endothelium as a contributor of plasma sphingosine 1-phosphate. Circ. Res. 2008, 102, 669-676. [CrossRef] [PubMed]

32. Hisano, Y.; Kobayashi, N.; Yamaguchi, A.; Nishi, T. Mouse SPNS2 functions as a Sphingosine-1-phosphate transporter in vascular endothelial cells. PLoS One 2012, 7, e38941. [CrossRef]

33. Fukuhara, S.; Simmons, S.; Kawamura, S.; Inoue, A.; Orba, Y.; Tokudome, T.; Sunden, Y.; Arai, Y.; Moriwaki, K.; Ishida, J.; et al. The sphingosine-1-phosphate transporter Spns2 expressed on endothelial cells regulates lymphocyte trafficking in mice. J. Clin. Investig. 2012, 122, 1416-1426. [CrossRef] [PubMed]

34. Alvarez, S.E.; Harikumar, K.B.; Hait, N.C.; Allegood, J.; Strub, G.M.; Kim, E.Y.; Maceyka, M.; Jiang, H.; Luo, C.; Kordula, T.; et al. Sphingosine-1-phosphate is a missing cofactor for the E3 ubiquitin ligase TRAF2. Nature 2010, 465, 1084-1088. [CrossRef]

35. Spiegel, S.; Milstien, S. The outs and the ins of sphingosine-1-phosphate in immunity. Nat. Rev. Immunol. 2011, 11, 403-415. [CrossRef]

36. Kajimoto, T.; Caliman, A.D.; Tobias, I.S.; Okada, T.; Pilo, C.A.; Van, A.-A. N.; McCammon, J.A.; Nakamura, S.-I.; Newton, A.C. Activation of atypical protein kinase C by sphingosine 1-phosphate revealed by an aPKC-specific activity reporter. Sci. Signal. 2019, 12, eaat6662. [CrossRef] [PubMed]

37. Adams, D.R.; Ron, D.; Kiely, P.A. RACK1, a multifaceted scaffolding protein: Structure and function. Cell Commun. Signal. 2011, 9, 22. [CrossRef]

38. Steinberg, S.F. Structural basis of protein kinase C isoform function. Physiol. Rev. 2008, 88, 1341-1378. [CrossRef]

39. Moscat, J.; Diaz-Meco, M.T. The atypical protein kinase Cs: Functional specificity mediated by specific protein adapters. EMBO Rep. 2000, 1, 399-403. [CrossRef]

40. Li, S.; Wang, L.; Dorf, M.E. PKC phosphorylation of TRAF2 mediates IKK $\alpha / \beta$ recruitment and K63-linked polyubiquitination. Mol. Cell. 2009, 33, 30-42. [CrossRef]

41. Etemadi, N.; Chopin, M.; Anderton, H.; Tanzer, M.C.; Rickard, J.A.; Abeysekera, W.; Hall, C.; Spall, S.; Wang, B.; Xiong, Y.; et al. TRAF2 regulates TNF and NF-kB signalling to suppress apoptosis and skin inflammation independently of sphingosine kinase. Elife 2015, 4, e10592. [CrossRef] [PubMed]

42. Kanayama, A.; Seth, R.B.; Sun, L.; Ea, C.-K.; Hong, M.; Shaito, A.; Chiu, Y.-H.; Deng, L.; Chen, Z.J. TAB2 and TAB3 activate the NF-кB pathway through binding to polyubiquitin chains. Mol. Cell. 2004, 15, 535-548. [CrossRef] [PubMed] 
43. Deng, L.; Wang, C.; Spencer, E.; Yang, L.; Braun, A.; You, J.; Slaughter, C.; Pickart, C.; Chen, Z.J. Activation of the Ikb kinase complex by TRAF6 requires a dimeric ubiquitin-conjugating enzyme complex and a unique polyubiquitin chain. Cell 2000, 103, 351-361. [CrossRef]

44. Manning, E.; Pullen, S.S.; Souza, D.J.; Kehry, M.; Noelle, R.J. Cellular responses to murine CD40 in a mouse B cell line may be TRAF dependent or independent. Eur. J. Immunol. 2002, 32, 39-49. [CrossRef]

45. Tontonoz, P.; Spiegelman, B.M. Fat and beyond: The diverse biology of PPAR $\gamma$. Annu. Rev. Biochem. 2008, 77, 289-312. [CrossRef]

46. Parham, K.A.; Zebol, J.R.; Tooley, K.L.; Sun, W.Y.; Moldenhauer, L.M.; Cockshell, M.P.; Gliddon, B.L.; Moretti, P.A.; Tigyi, G.; Pitson, S.M.; et al. Sphingosine 1-phosphate is a ligand for peroxisome proliferator-activated receptor- $\gamma$ that regulates neoangiogenesis. FASEB J. 2015, 29, 3638-3653. [CrossRef]

47. Ogretmen, B. Sphingolipid metabolism in cancer signalling and therapy. Nat. Rev. Cancer 2018, 18, 33-50. [CrossRef]

48. Maceyka, M.; Sankala, H.; Hait, N.C.; Le Stunff, H.; Liu, H.; Toman, R.; Collier, C.; Zhang, M.; Satin, L.S.; Merrill, A.H., Jr.; et al. SphK1 and SphK2, sphingosine kinase isoenzymes with opposing functions in sphingolipid metabolism. J. Biol. Chem. 2005, 280, 37118-37129. [CrossRef]

49. Igarashi, N.; Okada, T.; Hayashi, S.; Fujita, T.; Jahangeer, S.; Nakamura, S.-I. Sphingosine kinase 2 is a nuclear protein and inhibits DNA synthesis. J. Biol. Chem. 2003, 278, 46832-46839. [CrossRef]

50. Sankala, H.M.; Hait, N.C.; Paugh, S.W.; Shida, D.; Lépine, S.; Elmore, L.W.; Dent, P.; Milstien, S.; Spiegel, S. Involvement of sphingosine kinase 2 in p53-independent induction of p21 by the chemotherapeutic drug doxorubicin. Cancer Res. 2007, 67, 10466-10474. [CrossRef]

51. Ding, G.; Sonoda, H.; Yu, H.; Kajimoto, T.; Goparaju, S.K.; Jahangeer, S.; Okada, T.; Nakamura, S.-I. Protein kinase D-mediated phosphorylation and nuclear export of sphingosine kinase 2. J. Biol. Chem. 2007, 282, 27493-27502. [CrossRef] [PubMed]

52. Spiegel, S.; Maczis, M.A.; Maceyka, M.; Milstien, S. New insights into functions of the sphingosine-1-phosphate transporter SPNS2. J. Lipid Res. 2019, 60, 484-489. [CrossRef] [PubMed]

53. Hait, N.C.; Allegood, J.; Maceyka, M.; Strub, G.M.; Harikumar, K.B.; Singh, S.K.; Luo, C.; Marmorstein, R.; Kordula, T.; Milstien, S.; et al. Regulation of histone acetylation in the mucleus by sphingosine-1-phosphate. Science 2009, 325, 1254-1257. [CrossRef]

54. Jamaladdin, S.; Kelly, R.D.W.; O’Regan, L.; Dovey, O.M.; Hodson, G.E.; Millard, C.J.; Portolano, N.; Fry, A.M.; Schwabe, J.W.R.; Cowley, S.M. Histone deacetylase (HDAC) 1 and 2 are essential for accurate cell division and the pluripotency of embryonic stem cells. Proc. Natl. Acad. Sci. USA 2014, 111, 9840-9845. [CrossRef] [PubMed]

55. Choudhary, C.; Kumar, C.; Gnad, F.; Nielsen, M.L.; Rehman, M.; Walther, T.C.; Olsen, J.V.; Mann, M. Lysine acetylation targets protein complexes and co-regulates major cellular functions. Science 2009, 325, 834-840. [CrossRef]

56. Kelly, R.D.W.; Chandru, A.; Watson, P.J.; Song, Y.; Blades, M.; Robertson, N.S.; Jamieson, A.G.; Schwabe, J.W.R.; Cowley, S.M. Histone deacetylase (HDAC) 1 and 2 complexes regulate both histone acetylation and crotonylation in vivo. Sci. Rep. 2018, 8, 14690. [CrossRef] [PubMed]

57. Panneer Selvam, S.; De Palma, R.M.; Oaks, J.J.; Oleinik, N.; Peterson, Y.K.; Stahelin, R.V.; Skoralakes, E.; Ponnusamy, S.; Garrett-Mayer, E.; Smith, C.D.; et al. Binding of the sphingolipid S1P to hTERT stabilizes telomerase at the nuclear periphery by allosterically mimicking protein phosphorylation. Sci. Signal. 2015, 8, ra58. [CrossRef]

58. Kim, J.H.; Park, S.-M.; Kang, M.R.; Oh, S.-Y.; Lee, T.H.; Muller, M.T.; Chung, I.K. Ubiquitin ligase MKRN1 modulates telomere length homeostasis through a proteolysis of hTERT. Genes Dev. 2005, 19, 776-781. [CrossRef]

59. Murata, N.; Sato, K.; Kon, J.; Tomura, H.; Yanagita, M.; Kuwabara, A.; Ui, M.; Okajima, F. Interaction of sphingosine 1-phosphate with plasma components, including lipoproteins, regulates the lipid receptor-mediated actions. Biochem. J. 2000, 352, 809-815. [CrossRef]

60. Argraves, K.M.; Argraves, W.S. HDL serves as a S1P signaling platform mediating a multitude of cardiovascular effects. J. Lipid Res. 2007, 48, 2325-2333. [CrossRef]

61. Christoffersen, C.; Obinata, H.; Kumaraswamy, S.B.; Galvani, S.; Ahnström, J.; Sevvana, M.; Egerer-Sieber, C.; Muller, Y.A.; Hla, T.; Nielsen, L.B.; et al. Endothelium-protective sphingosine-1-phosphate provided by HDL-associated apolipoprotein M. Proc. Natl. Acad. Sci. USA 2011, 108, 9613-9618. [CrossRef] [PubMed] 
62. Kurano, M.; Tsukamoto, K.; Ohkawa, R.; Hara, M.; Iino, J.; Kageyama, Y.; Ikeda, H.; Yatomi, Y. Liver involvement in sphingosine 1-phosphate dynamism revealed by adenoviral hepatic overexpression of apolipoprotein M. Atherosclerosis. 2013, 229, 102-109. [CrossRef] [PubMed]

63. Liu, M.; Seo, J.; Allegood, J.; Bi, X.; Zhu, X.; Boudyguina, E.; Gebre, A.K.; Avni, D.; Shah, D.; Sorci-Thomas, M.G.; et al. Hepatic apolipoprotein M (ApoM) overexpression stimulates formation of larger ApoM/sphingosine 1-phosphate-enriched plasma high density lipoprotein. J. Biol. Chem. 2014, 289, 2801-2814. [CrossRef]

64. Lee, M.J.; Thangada, S.; Claffey, K.P.; Ancellin, N.; Liu, C.H.; Kluk, M.; Volpi, M.; Sha'afi, R.I.; Hla, T. Vascular endothelial cell adherens junction assembly and morphogenesis induced by sphingosine-1-phosphate. Cell 1999, 99, 301-312. [CrossRef]

65. Sanchez, T.; Estrada-Hernandez, T.; Paik, J.-H.; Wu, M.-T.; Venkataraman, K.; Brinkmann, V.; Claffey, K.; Hla, T. Phosphorylation and action of the immunomodulator FTY720 inhibits vascular endothelial cell growth factor-induced vascular permeability. J. Biol. Chem. 2003, 278, 47281-47290. [CrossRef] [PubMed]

66. Cyster, J.G.; Schwab, S.R. Sphingosine-1-phosphate and lymphocyte egress from lymphoid organs. Annu. Rev. Immunol. 2012, 30, 69-94. [CrossRef]

67. Blaho, V.A.; Hla, T. An update on the biology of sphingosine 1-phosphate receptors. J. Lipid Res. 2014, 55, 1596-1608. [CrossRef]

68. Regard, J.B.; Sato, I.T.; Coughlin, S.R. Anatomical profiling of G protein-coupled receptor expression. Cell 2008, 135, 561-571. [CrossRef]

69. Garcia, J.G.; Liu, F.; Verin, A.D.; Birukova, A.; Dechert, M.A.; Gerthoffer, W.T.; Bamberg, J.R.; English, D. Sphingosine 1-phosphate promotes endothelial cell barrier integrity by Edg-dependent cytoskeletal rearrangement. J. Clin. Investig. 2001, 108, 689-701. [CrossRef]

70. Rosen, H.; Goetzl, E.J. Sphingosine 1-phosphate and its receptors: An autocrine and paracrine network. Nat. Rev. Immunol. 2005, 5, 560-570. [CrossRef]

71. Alvarez, S.E.; Milstien, S.; Spiegel, S. Autocrine and paracrine roles of sphingosine-1-phosphate. Trends Endocrinol. Metab. 2007, 18, 300-307. [CrossRef]

72. Rosen, H.; Stevens, R.C.; Hanson, M.; Roberts, E.; Oldstone, M.B.A. Sphingosine-1-phosphate and its receptors: Structure, signaling, and influence. Annu. Rev. Biochem. 2013, 82, 637-662. [CrossRef]

73. Badawy, S.M.M.; Okada, T.; Kajimoto, T.; Ijuin, T.; Nakamura, S.I. DHHC5-mediated palmitoylation of S1P receptor subtype 1 determines G-protein coupling. Sci. Rep. 2017, 7, 16552. [CrossRef] [PubMed]

74. Kono, M.; Tucker, A.E.; Tran, J.; Bergner, J.B.; Turner, E.M.; Proia, R.L. Sphingosine-1-phosphate receptor 1 reporter mice reveal receptor activation sites in vivo. J. Clin. Investig. 2014, 124, 2076-2086. [CrossRef]

75. Kono, M.; Conlon, E.G.; Lux, S.Y.; Yanagida, K.; Hla, T.; Proia, R.L. Bioluminescence imaging of G protein-coupled receptor activation in living mice. Nat. Commun. 2017, 8, 1163. [CrossRef] [PubMed]

76. Arnon, T.I.; Xu, Y.; Lo, C.; Pham, T.; An, J.; Coughlin, S.; Dorn, G.W.; Cyster, J.G. GRK2-dependent S1PR1 desensitization is required for lymphocytes to overcome their attraction to blood. Science 2011, 333, 1898-1903. [CrossRef] [PubMed]

77. Thangada, S.; Khanna, K.M.; Blaho, V.A.; Oo, M.L.; Im, D.-S.; Guo, C.; Lefrancois, L.; Hla, T. Cell-surface residence of sphingosine 1-phosphate receptor 1 on lymphocytes determines lymphocyte egress kinetics. J. Exp. Med. 2010, 207, 1475-1483. [CrossRef]

78. Willinger, T.; Ferguson, S.M.; Pereira, J.P.; De Camilli, P.; Flavell, R.A. Dynamin 2-dependent endocytosis is required for sustained S1PR1 signaling. J. Exp. Med. 2014, 211, 685-700. [CrossRef]

79. Nomachi, A.; Yoshinaga, M.; Liu, J.; Kanchanawong, P.; Tohyama, K.; Thumkeo, D.; Watanabe, T.; Narumiya, S.; Hirata, T. Moesin controls clathrin-mediated S1PR1 internalization in T cells. PLoS ONe 2013, 8, e82590. [CrossRef]

80. Liu, C.H.; Thangada, S.; Lee, M.J.; Van Brooklyn, J.R.; Spiegel, S.; Hla, T. Ligand-induced trafficking of the sphingosine-1-phosphate receptor EDG- 1. Mol. Biol. Cell. 1999, 10, 1179-1190. [CrossRef]

81. Oo, M.L.; Chang, S.H.; Thangada, S.; Wu, M.-T.; Rezaul, K.; Blaho, V.; Hwang, S.-I.; Han, D.K.; Hla, T. Engagement of S1P1-degradative mechanisms leads to vascular leak in mice. J. Clin. Investig. 2011, 121, 2290-2300. [CrossRef] [PubMed]

82. Schulze, H.; Kolter, T.; Sandhoff, K. Principles of lysosomal membrane degradation: Cellular topology and biochemistry of lysosomal lipid degradation. Biochim. Biophys. Acta 2009, 1793, 674-683. [CrossRef] [PubMed] 
83. Luzio, J.P.; Gray, S.R.; Bright, N.A. Endosome-lysosome fusion. Biochem. Soc. Trans. 2010, 38, $1413-1416$. [CrossRef] [PubMed]

84. Lawrence, R.E.; Zoncu, R. The lysosome as a cellular centre for signalling, metabolism and quality control. Nat. Cell Biol. 2019, 21, 133-142. [CrossRef]

85. Kitatani, K.; Idkowiak-Baldys, J.; Hannun, Y.A. The sphingolipid salvage pathway in ceramide metabolism and signaling. Cell Signal. 2008, 20, 1010-1018. [CrossRef]

86. Proia, R.L.; Hla, T. Emerging biology of sphingosine-1-phosphate: Its role in pathogenesis and therapy. J. Clin. Investig. 2015, 125, 1379-1387. [CrossRef] [PubMed]

87. Young, M.M.; Takahashi, Y.; Fox, T.E.; Yun, J.K.; Kester, M.; Wang, H.-G. Sphingosine kinase 1 cooperates with autophagy to maintain endocytic membrane trafficking. Cell Rep. 2016, 17, 1532-1545. [CrossRef] [PubMed]

88. Chun, J.; Hla, T.; Lynch, K.R.; Spiegel, S.; Moolenaar, W.H. International Union of Basic and Clinical Pharmacology. LXXVIII. Lysophospholipid receptor nomenclature. Pharmacol. Rev. 2010, 62, 579-587. [CrossRef] [PubMed]

89. Moon, E.; Han, J.E.; Jeon, S.; Ryu, J.H.; Choi, J.W.; Chun, J. Exogenous S1P exposure potentiates ischemic stroke damage that is reduced possibly by inhibiting S1P receptor signaling. Mediators Inflamm. 2015, 2015, 492659. [CrossRef]

90. Siehler, S.; Manning, D.R. Pathways of transduction engaged by sphingosine 1-phosphate through G protein-coupled receptors. Biochim. Biophys. Acta 2002, 1582, 94-99. [CrossRef]

91. Gonda, K.; Okamoto, H.; Takuwa, N.; Yatomi, Y.; Okazaki, H.; Sakurai, T.; Kimura, S.; Sillard, R.; Harii, K.; Takuwa, Y. The novel sphingosine 1-phosphate receptor AGR16 is coupled via pertussis toxin-sensitive and -insensitive G-proteins to multiple signalling pathways. Biochem. J. 1999, 337, 67-75. [CrossRef] [PubMed]

92. Windh, R.T.; Lee, M.J.; Hla, T.; An, S.; Barr, A.J.; Manning, D.R. Differential coupling of the sphingosine 1-phosphate receptors Edg-1, Edg-3, and H218/Edg-5 to the G(i), G(q), and G12 families of heterotrimeric G proteins. J. Biol. Chem. 1999, 274, 27351-27358. [CrossRef] [PubMed]

93. Okamoto, H.; Takuwa, N.; Yokomizo, T.; Sugimoto, N.; Sakurada, S.; Shigematsu, H.; Takuwa, Y. Inhibitory regulation of Rac activation, membrane ruffling, and cell migration by the $\mathrm{G}$ protein-coupled sphingosine-1-phosphate receptor EDG5 but not EDG1 or EDG3. Mol. Cell Biol. 2000, 20, 9247-9261. [CrossRef] [PubMed]

94. Ancellin, N.; Hla, T. Differential pharmacological properties and signal transduction of the sphingosine 1-phosphate receptors EDG-1, EDG-3, and EDG-5. J. Biol. Chem. 1999, 274, 18997-19002. [CrossRef]

95. Graeler, M.; Goetzl, E.J. Activation-regulated expression and chemotactic function of sphingosine 1-phosphate receptors in mouse splenic T cells. FASEB J. 2002, 16, 1874-1878. [CrossRef]

96. Neves, S.R.; Ram, P.T.; Iyengar, R. G protein pathways. Science 2002, 296, 1636-1639. [CrossRef]

97. Ghosh, P.; Rangamani, P.; Kufareva, I. The GAPs, GEFs, GDIs and ... now, GEMs: New kids on the heterotrimeric $G$ protein signaling block. Cell Cycle. 2017, 16, 607-612. [CrossRef]

98. Oldham, W.M.; Hamm, H.E. Heterotrimeric G protein activation by G-protein-coupled receptors. Nat. Rev. Mol. Cell Biol. 2008, 9, 60-71. [CrossRef]

99. Smith, J.S.; Lefkowitz, R.J.; Rajagopal, S. Biased signalling: From simple switches to allosteric microprocessors. Nat. Rev. Drug Discov. 2018, 17, 243-260. [CrossRef]

100. Feistritzer, C.; Riewald, M. Endothelial barrier protection by activated protein C through PAR1-dependent sphingosine 1-phosphate receptor-1 crossactivation. Blood 2005, 105, 3178-3184. [CrossRef]

101. Singleton, P.A.; Dudek, S.M.; Ma, S.-F.; Garcia, J.G.N. Transactivation of sphingosine 1-phosphate receptors is essential for vascular barrier regulation: Novel role for hyaluronan and CD44 receptor family. J. Biol. Chem. 2006, 281, 34381-34393. [CrossRef] [PubMed]

102. Shiow, L.R.; Rosen, D.B.; Brdičková, N.; Xu, Y.; An, J.; Lanier, L.L.; Cyster, J.G.; Matloubian, M. CD69 acts downstream of interferon $\alpha / \beta$ to inhibit S1P1 and lymphocyte egress from lymphoid organs. Nature 2006, 440, 540-544. [CrossRef] [PubMed]

103. Hisano, Y.; Kono, M.; Cartier, A.; Engelbrecht, E.; Kano, K.; Kawakami, K.; Xiong, Y.; Piao, W.; Galvani, S.; Yanagida, K.; et al. Lysolipid receptor cross-talk regulates lymphatic endothelial junctions in lymph nodes. J. Exp. Med. 2019, 216, 1582-1598. [CrossRef] [PubMed]

104. Laidlaw, B.J.; Gray, E.E.; Zhang, Y.; Ramírez-Valle, F.; Cyster, J.G. Sphingosine-1-phosphate receptor 2 restrains egress of $\gamma \delta$ T cells from the skin. J. Exp. Med. 2019, 216, 1487-1496. [CrossRef] [PubMed] 
105. Kempf, A.; Tews, B.; Arzt, M.E.; Weinmann, O.; Obermair, F.J.; Pernet, V.; Zagrebelsky, M.; Delekate, A.; Iobbi, C.; Zemmar, A.; et al. The sphingolipid receptor S1PR2 is a receptor for Nogo-A repressing synaptic plasticity. PLoS Biol. 2014, 12, e1001763. [CrossRef]

106. Studer, E.; Zhou, X.; Zhao, R.; Wang, Y.; Takabe, K.; Nagahashi, M.; Pandak, W.M.; Dent, P.; Spiegel, S.; Shi, R.; et al. Conjugated bile acids activate the sphingosine-1-phosphate receptor 2 in primary rodent hepatocytes. Hepatology 2012, 55, 267-276. [CrossRef]

107. Wang, Y.; Chen, D.; Zhang, Y.; Wang, P.; Zheng, C.; Zhang, S.; Yu, B.; Zhang, L.; Zhao, G.; Ma, B.; et al. Novel adipokine, FAM19A5, inhibits neointima formation after injury through sphingosine-1-phosphate receptor 2. Circulation 2018, 138, 48-63. [CrossRef]

108. Peng, C.; Trojanowski, J.Q.; Lee, V.M.-Y. Protein transmission in neurodegenerative disease. Nat. Rev. Neurol. 2020, 16, 199-212. [CrossRef]

109. Goedert, M.; Masuda-Suzukake, M.; Falcon, B. Like prions: The propagation of aggregated tau and $\alpha$-synuclein in neurodegeneration. Brain 2017, 140, 266-278. [CrossRef]

110. Angot, E.; Steiner, J.A.; Hansen, C.; Li, J.-Y.; Brundin, P. Are synucleinopathies prion-like disorders? Lancet Neurol. 2010, 9, 1128-1138. [CrossRef]

111. Aguzzi, A.; Nuvolone, M.; Zhu, C. The immunobiology of prion diseases. Nat. Rev. Immunol. 2013, 13, 888-902. [CrossRef] [PubMed]

112. Shubhra Chakrabarti, S.; Bir, A.; Poddar, J.; Sinha, M.; Ganguly, A.; Chakrabarti, S. Ceramide and sphingosine-1-phosphate in cell death pathways: Relevance to the pathogenesis of Alzheimer's disease. Curr. Alzheimer Res. 2016, 13, 1232-1248. [CrossRef] [PubMed]

113. Di Paolo, G.; Kim, T.-W. Linking lipids to Alzheimer's disease: Cholesterol and beyond. Nat. Rev. Neurosci. 2011, 12, 284-296. [CrossRef] [PubMed]

114. Van Echten-Deckert, G.; Walter, J. Sphingolipids: Critical players in Alzheimer's disease. Prog. Lipid Res. 2012, 51, 378-393. [CrossRef]

115. Lemkul, J.A.; Bevan, D.R. Lipid composition influences the release of Alzheimer's amyloid $\beta$-peptide from membranes. Protein Sci. 2011, 20, 1530-1545. [CrossRef] [PubMed]

116. Grassi, S.; Giussani, P.; Mauri, L.; Prioni, S.; Sonnino, S.; Prinetti, A. Lipid rafts and neurodegeneration: Structural and functional roles in physiologic aging and neurodegenerative diseases. J. Lipid Res. 2020, 61, 636-654. [CrossRef] [PubMed]

117. Crivelli, S.M.; Giovagnoni, C.; Visseren, L.; Scheithauer, A.-L.; de Wit, N.; den Hoedt, S.; Losen, M.; Mulder, M.T.; Walter, J.; de Vries, H.E. et al.; et al. Sphingolipids in Alzheimer's disease, how can we target them? Adv. Drug Deliv. Rev 2020, S0169-409X(20)30002-8. [CrossRef] [PubMed]

118. Kisler, K.; Nelson, A.R.; Montagne, A.; Zlokovic, B.V. Cerebral blood flow regulation and neurovascular dysfunction in Alzheimer disease. Nat. Rev. Neurosci. 2017, 18, 419-434. [CrossRef] [PubMed]

119. Iadecola, C. The pathobiology of vascular dementia. Neuron 2013, 80, 844-866. [CrossRef]

120. Iadecola, C. Neurovascular regulation in the normal brain and in Alzheimer's disease. Nat. Rev. Neurosci. 2004, 5, 347-360. [CrossRef]

121. Zlokovic, B.V. Neurovascular pathways to neurodegeneration in Alzheimer's disease and other disorders. Nat. Rev. Neurosci. 2011, 12, 723-738. [CrossRef] [PubMed]

122. Toledo, J.B.; Cairns, N.J.; Da, X.; Chen, K.; Carter, D.; Fleisher, A.; Householder, E.; Ayutyanont, N.; Roontiva, A.; Bauer, R.J.; et al. Clinical and multimodal biomarker correlates of ADNI neuropathological findings. Acta Neuropathol. Commun. 2013, 1, 65. [CrossRef] [PubMed]

123. Montagne, A.; Barnes, S.R.; Sweeney, M.D.; Halliday, M.R.; Sagare, A.P.; Zhao, Z.; Toga, A.W.; Jacobs, R.E.; Liu, C.Y.; Amezcua, L.; et al. Blood-brain barrier breakdown in the aging human hippocampus. Neuron 2015, 85, 296-302. [CrossRef] [PubMed]

124. Sweeney, M.D.; Sagare, A.P.; Zlokovic, B.V. Cerebrospinal fluid biomarkers of neurovascular dysfunction in mild dementia and Alzheimer's disease. J. Cereb. Blood Flow Metab. 2015, 35, 1055-1068. [CrossRef]

125. Arvanitakis, Z.; Capuano, A.W.; Leurgans, S.E.; Bennett, D.A.; Schneider. JA. Relation of cerebral vessel disease to Alzheimer's disease dementia and cognitive function in elderly people: A cross-sectional study. Lancet Neurol. 2016, 15, 934-943. [CrossRef]

126. Iturria-Medina, Y.; Sotero, R.C.; Toussaint, P.J.; Mateos-Pérez, J.M.; Evans, A.C. Early role of vascular dysregulation on late-onset Alzheimer's disease based on multifactorial data-driven analysis. Nat. Commun. 2016, 7, 11934. [CrossRef] 
127. Nelson, A.R.; Sweeney, M.D.; Sagare, A.P.; Zlokovic, B.V. Neurovascular dysfunction and neurodegeneration in dementia and Alzheimer's disease. Biochim. Biophys. Acta 2016, 1862, 887-900. [CrossRef]

128. Becker, K.A.; Fahsel, B.; Kemper, H.; Mayeres, J.; Li, C.; Wilker, B.; Keitsch, S.; Soddemann, M.; Sehl, C.; Kohnen, M.; et al. Staphylococcus aureus alpha-toxin disrupts endothelial-cell tight junctions via acid sphingomyelinase and ceramide. Infect. Immun. 2017, 86, e00606-17. [CrossRef]

129. van Doorn, R.; Nijland, P.G.; Dekker, N.; Witte, M.E.; Lopes-Pinheiro, M.A.; van het Hof, B.; Kooij, G.; Reijerkerk, A.; Dijkstra, C.; van van der Valk, P.; et al. Fingolimod attenuates ceramide-induced blood-brain barrier dysfunction in multiple sclerosis by targeting reactive astrocytes. Acta Neuropathol. 2012, 124, 397-410. [CrossRef]

130. Cutler, R.G.; Kelly, J.; Storie, K.; Pedersen, W.A.; Tammara, A.; Hatanpaa, K.; Troncoso, J.C.; Mattson, M.P. Involvement of oxidative stress-induced abnormalities in ceramide and cholesterol metabolism in brain aging and Alzheimer's disease. Proc. Natl. Acad. Sci. USA 2004, 101, 2070-2075. [CrossRef]

131. Han, X.; Holtzman, D.M.; McKeel, D.W., Jr.; Kelley, J.; Morris, J.C. Substantial sulfatide deficiency and ceramide elevation in very early Alzheimer's disease: Potential role in disease pathogenesis. J. Neurochem. 2002, 82, 809-818. [CrossRef]

132. He, X.; Huang, Y.; Li, B.; Gong, C.-X.; Schuchman, E.H. Deregulation of sphingolipid metabolism in Alzheimer's disease. Neurobiol. Aging 2010, 31, 398-408. [CrossRef]

133. Filippov, V.; Song, M.A.; Zhang, K.; Vinters, H.V.; Tung, S.; Kirsch, W.M.; Yang, J.; Duerksen-Hughes, P.J. Increased ceramide in brains with alzheimer's and other neurodegenerative diseases. J. Alzheimer's Dis. 2012, 29, 537-547. [CrossRef] [PubMed]

134. Couttas, T.A.; Kain, N.; Daniels, B.; Lim, X.Y.; Shepherd, C.; Kril, J.; Pickford, R.; Li, H.; Garner, B.; Don, A.S. Loss of the neuroprotective factor sphingosine 1-phosphate early in Alzheimer's disease pathogenesis. Acta Neuropathol. Commun. 2014, 2, 9. [CrossRef]

135. Katsel, P.; Li, C.; Haroutunian, V. Gene expression alterations in the sphingolipid metabolism pathways during progression of dementia and Alzheimer's disease: A shift toward ceramide accumulation at the earliest recognizable stages of Alzheimer's disease? Neurochem. Res. 2007, 32, 845-856. [CrossRef] [PubMed]

136. Ceccom, J.; Loukh, N.; Lauwers-Cances, V.; Touriol, C.; Nicaise, Y.; Gentil, C.; Uro-Coste, E.; Pitson, S.; Maurage, C.A.; Duyckaerts, C.; et al. Reduced sphingosine kinase-1 and enhanced sphingosine 1-phosphate lyase expression demonstrate deregulated sphingosine 1-phosphate signaling in Alzheimer's disease. Acta Neuropathol. Commun. 2014, 2, 12. [CrossRef]

137. Dominguez, G.; Maddelein, M.-L.; Pucelle, M.; Nicaise, Y.; Maurage, C.-A.; Duyckaerts, C.; Cuvillier, O.; Delisle, M.-B. Neuronal sphingosine kinase 2 subcellular localization is altered in Alzheimer's disease brain. Acta Neuropathol. Commun. 2018, 6, 25. [CrossRef]

138. Xilouri, M.; Vogiatzi, T.; Vekrellis, K.; Stefanis, L. $\alpha$-synuclein degradation by autophagic pathways: A potential key to Parkinson's disease pathogenesis. Autophagy 2008, 4, 917-919. [CrossRef] [PubMed]

139. Dehay, B.; Martinez-Vicente, M.; Caldwell, G.A.; Caldwell, K.A.; Yue, Z.; Cookson, M.R.; Klein, C.; Vila, M.; Bezard, E. Lysosomal impairment in Parkinson's disease. Mov. Disord. 2013, 28, 725-732. [CrossRef]

140. Manzoni, C.; Lewis, P.A. Dysfunction of the autophagy/lysosomal degradation pathway is a shared feature of the genetic synucleinopathies. FASEB J. 2013, 27, 3424-3429. [CrossRef]

141. Lwin, A.; Orvisky, E.; Goker-Alpan, O.; LaMarca, M.E.; Sidransky, E. Glucocerebrosidase mutations in subjects with parkinsonism. Mol. Genet. Metab. 2004, 81, 70-73. [CrossRef] [PubMed]

142. Neumann, J.; Bras, J.; Deas, E.; O’Sullivan, S.S.; Parkkinen, L.; Lachmann, R.H.; Li, A.; Holton, J.; Guerreiro, R.; Paudel, R.; et al. Glucocerebrosidase mutations in clinical and pathologically proven Parkinson's disease. Brain 2009, 132, 1783-1794. [CrossRef] [PubMed]

143. Mata, I.F.; Samii, A.; Schneer, S.H.; Roberts, J.W.; Griffith, A.; Leis, B.C.; Schellenberg, G.D.; Sidransky, E.; Bird, T.D.; Leverenz, J.B.; et al. Glucocerebrosidase gene mutations: A risk factor for Lewy body disorders. Arch. Neurol. 2008, 65, 379-382. [CrossRef] [PubMed]

144. Bras, J.; Singleton, A.; Cookson, M.R.; Hardy, J. Emerging pathways in genetic Parkinson's disease: Potential role of ceramide metabolism in Lewy body disease. FEBS J. 2008, 275, 5767-5773. [CrossRef] [PubMed]

145. Sidransky, E. Gaucher disease and parkinsonism. Mol. Genet. Metab. 2005, 84, 302-304. [CrossRef]

146. Sidransky, E.; Lopez, G. The link between the GBA gene and parkinsonism. Lancet Neurol. 2012, 11, 986-998. [CrossRef] 
147. Mazzulli, J.R.; Xu, Y.-H.; Sun, Y.; Knight, A.L.; McLean, P.J.; Caldwell, G.A.; Sidransky, E.; Grabowski, G.A.; Krainc, D. Gaucher disease glucocerebrosidase and $\alpha$-synuclein form a bidirectional pathogenic loop in synucleinopathies. Cell 2011, 146, 37-52. [CrossRef]

148. Taguchi, Y.V.; Liu, J.; Ruan, J.; Pacheco, J.; Zhang, X.; Abbasi, J.; Keutzer, J.; Mistry, P.K.; Chandra, S.S. Glucosylsphingosine promotes $\alpha$-synuclein pathology in mutant GBA-associated parkinson's disease. J. Neurosci. 2017, 37, 9617-9631. [CrossRef]

149. Everett, C.M.; Wood, N.W. Trinucleotide repeats and neurodegenerative disease. Brain 2004, 127, $2385-2405$. [CrossRef]

150. Jimenez-Sanchez, M.; Licitra, F.; Underwood, B.R.; Rubinsztein, D.C. Huntington's disease: Mechanisms of pathogenesis and therapeutic strategies. Cold Spring Harb. Perspect. Med. 2017, 7, a024240. [CrossRef]

151. Di Pardo, A.; Amico, E.; Basit, A.; Armirotti, A.; Joshi, P.; Neely, M.D.; Vuono, R.; Castaldo, S.; Digilio, A.F.; Scalabrì, F.; et al. Defective sphingosine-1-phosphate metabolism is a druggable target in Huntington's disease. Sci. Rep. 2017, 7, 5280. [CrossRef] [PubMed]

152. Pirhaji, L.; Milani, P.; Dalin, S.; Wassie, B.T.; Dunn, D.E.; Fenster, R.J.; Avila-Pacheco, J.; Greengard, P.; Clish, C.B.; Heiman, M.; et al. Identifying therapeutic targets by combining transcriptional data with ordinal clinical measurements. Nat. Commun. 2017, 8, 623. [CrossRef] [PubMed]

153. Di Pardo, A.; Maglione, V. The S1P axis: New exciting route for treating Huntington's disease. Trends Pharmacol. Sci. 2018, 39, 468-480. [CrossRef] [PubMed]

154. Henriques, A.; Croixmarie, V.; Bouscary, A.; Mosbach, A.; Keime, C.; Boursier-Neyret, C.; Walter, B.; Spedding, M.; Loeffler, J.-P. Sphingolipid metabolism is dysregulated at transcriptomic and metabolic levels in the spinal cord of an animal model of amyotrophic lateral sclerosis. Front. Mol. Neurosci. 2018, 10, 433. [CrossRef] [PubMed]

155. Brinkmann, V.; Davis, M.D.; Heise, C.E.; Albert, R.; Cottens, S.; Hof, R.; Bruns, C.; Prieschl, E.; Baumruker, T.; Hiestand, P.; et al. The immune modulator FTY720 targets sphingosine 1-phosphate receptors. J. Biol. Chem. 2002, 277, 21453-21457. [CrossRef] [PubMed]

156. Mandala, S.; Hajdu, R.; Bergstrom, J.; Quackenbush, E.; Xie, J.; Milligan, J.; Thornton, R.; Shei, G.-J.; Card, D.; Keohane, C.; et al. Alteration of lymphocyte trafficking by sphingosine-1-phosphate receptor agonists. Science 2002, 296, 346-349. [CrossRef]

157. Potenza, R.L.; De Simone, R.; Armida, M.; Mazziotti, V.; Pèzzola, A.; Popoli, P.; Minghetti, L. Fingolimod: A disease-modifier drug in a mouse model of amyotrophic lateral sclerosis. Neurotherapeutics 2016, 13, 918-927. [CrossRef]

158. Compston, A.; Coles, A. Multiple sclerosis. Lancet 2008, 372, 1502-1517. [CrossRef]

159. Constantinescu, C.S.; Farooqi, N.; O’Brien, K.; Gran, B. Experimental autoimmune encephalomyelitis (EAE) as a model for multiple sclerosis (MS). Br. J. Pharmacol. 2011, 164, 1079-1106. [CrossRef]

160. Grant, J.L.; Ghosn, E.E.B.; Axtell, R.C.; Herges, K.; Kuipers, H.F.; Woodling, N.S.; Andreasson, K.; Herzenberg, L.A.; Herzenberg, L.A.; Steinman, L. Reversal of paralysis and reduced inflammation from peripheral administration of $\beta$-amyloid in TH1 and TH17 versions of experimental autoimmune encephalomyelitis. Sci. Transl. Med. 2012, 4, 145ra105. [CrossRef]

161. Gijbels, K.; Engelborghs, S.; De Deyn, P.P. Experimental autoimmune encephalomyelitis: An animal model for multiple sclerosis. Neurosci. Res. Commun. 2000, 26, 193-206. [CrossRef]

162. Brinkmann, V.; Billich, A.; Baumruker, T.; Heining, P.; Schmouder, R.; Francis, G.; Aradhye, S.; Burtin, P. Fingolimod (FTY720): Discovery and development of an oral drug to treat multiple sclerosis. Nat. Rev. Drug Discov. 2010, 9, 883-897. [CrossRef] [PubMed]

163. Fujino, M.; Funeshima, N.; Kitazawa, Y.; Kimura, H.; Amemiya, H.; Suzuki, S.; Li, X.-K. Amelioration of experimental autoimmune encephalomyelitis in Lewis rats by FTY720 treatment. J. Pharmacol. Exp. Ther. 2003, 305, 70-77. [CrossRef] [PubMed]

164. Webb, M.; Tham, C.-S.; Lin, F.-F.; Lariosa-Willingham, K.; Yu, N.; Hale, J.; Mandala, S.; Chun, J.; Rao, T.S. Sphingosine 1-phosphate receptor agonists attenuate relapsing-remitting experimental autoimmune encephalitis in SJL mice. J. Neuroimmunol. 2004, 153, 108-121. [CrossRef] [PubMed]

165. Kataoka, H.; Sugahara, K.; Shimano, K.; Teshima, K.; Koyama, M.; Fukunari, A.; Chiba, K. FTY720, sphingosine 1-phosphate receptor modulator, ameliorates experimental autoimmune encephalomyelitis by inhibition of T cell infiltration. Cell Mol. Immunol. 2005, 2, 439-448. 
166. Foster, C.A.; Mechtcheriakova, D.; Storch, M.K.; Balatoni, B.; Howard, L.M.; Bornancin, F.; Wlachos, A.; Sobanov, J.; Kinnunen, A.; Baumruker, T. FTY720 rescue therapy in the dark agouti rat model of experimental autoimmune encephalomyelitis: Expression of central nervous system genes and reversal of blood-brain-barrier damage. Brain Pathol. 2009, 19, 254-266. [CrossRef]

167. Choi, J.W.; Gardell, S.E.; Herr, D.R.; Rivera, R.; Lee, C.-W.; Noguchi, K.; Teo, S.T.; Yung, Y.C.; Lu, M.; Kennedy, G.; et al. FTY720 (fingolimod) efficacy in an animal model of multiple sclerosis requires astrocyte sphingosine 1-phosphate receptor 1 (S1P1) modulation. Proc. Natl. Acad. Sci. USA 2011, 108, 751-756. [CrossRef]

168. Eken, A.; Duhen, R.; Singh, A.K.; Fry, M.; Buckner, J.H.; Kita, M.; Bettelli, E.; Oukka, M. S1P1 deletion differentially affects TH17 and regulatory T cells. Sci. Rep. 2017, 7, 12905. [CrossRef]

169. Smigiel, K.S.; Richards, E.; Srivastava, S.; Thomas, K.R.; Dudda, J.C.; Klonowski, K.D.; Campbell, D.J. CCR7 provides localized access to IL-2 and defines homeostatically distinct regulatory T cell subsets. J. Exp. Med. 2014, 211, 121-136. [CrossRef]

170. Cruz-Orengo, L.; Daniels, B.P.; Dorsey, D.; Basak, S.A.; Grajales-Reyes, J.G.; McCandless, E.E.; Piccio, L.; Schmidt, R.E.; Cross, A.H.; Crosby, S.D.; et al. Enhanced sphingosine-1-phosphate receptor 2 expression underlies female CNS autoimmunity susceptibility. J. Clin. Investig. 2014, 124, 2571-2584. [CrossRef]

171. Lopes Pinheiro, M.A.; Kroon, J.; Hoogenboezem, M.; Geerts, D.; van Het Hof, B.; van der Pol, S.M.A.; van Buul, J.D.; de Vries, H.E. Acid sphingomyelinase-derived ceramide regulates ICAM-1 function during T cell transmigration across brain endothelial cells. J. Immunol. 2016, 196, 72-79. [CrossRef] [PubMed]

172. Niessen, F.; Schaffner, F.; Furlan-Freguia, C.; Pawlinski, R.; Bhattacharjee, G.; Chun, J.; Derian, C.K.; Andrade-Gordon, P.; Rosen, H.; Ruf, W. Dendritic cell PAR1-S1P3 signalling couples coagulation and inflammation. Nature 2008, 452, 654-658. [CrossRef] [PubMed]

173. Fischer, I.; Alliod, C.; Martinier, N.; Newcombe, J.; Brana, C.; Pouly, S. Sphingosine kinase 1 and sphingosine 1-phosphate receptor 3 are functionally upregulated on astrocytes under pro-inflammatory conditions. PLoS ONE 2011, 6, e23905. [CrossRef] [PubMed]

174. Dusaban, S.S.; Chun, J.; Rosen, H.; Purcell, N.H.; Brown, J.H. Sphingosine 1-phosphate receptor 3 and RhoA signaling mediate inflammatory gene expression in astrocytes. J. Neuroinflammation 2017, 14, 111. [CrossRef]

175. Devic, E. Congrès français de médecine (Premiere Session; Lyon, 1894; procès-verbaux, mémoires et discussions; publiés par M. le Dr, L. Bard); Asselin et Houzeau: Lyon, France, 1895.

176. Gault, F. De la neuromyélite optique aiguë. Ph.D. Thesis, Faculté de Médecine Lyon Est, Lyon, France, 1894.

177. Wingerchuk, D.M.; Lennon, V.A.; Lucchinetti, C.F.; Pittock, S.J.; Weinshenker, B.G. The spectrum of neuromyelitis optica. Lancet Neurol. 2007, 6, 805-815. [CrossRef]

178. Weinshenker, B.G.; Wingerchuk, D.M.; Pittock, S.J.; Lucchinetti, C.F.; Lennon, V.A. NMO-IgG: A specific biomarker for neuromyelitis optica. Dis. Markers 2006, 22, 197-206. [CrossRef]

179. Jarius, S.; Franciotta, D.; Bergamaschi, R.; Wright, H.; Littleton, E.; Palace, J.; Hohlfeld, R.; Vincent, A. NMO-IgG in the diagnosis of neuromyelitis optica. Neurology 2007, 68, 1076-1077. [CrossRef]

180. Min, J.H.; Kim, B.J.; Lee, K.H. Development of extensive brain lesions following fingolimod (FTY720) treatment in a patient with neuromyelitis optica spectrum disorder. Mult. Scler. 2012, 18, 113-115. [CrossRef]

181. Yoshii, F.; Moriya, Y.; Ohnuki, T.; Ryo, M.; Takahashi, W. Fingolimod-induced leukoencephalopathy in a patient with neuromyelitis optica spectrum disorder. Mult. Scler. Relat Disord. 2016, 7, 53-57. [CrossRef]

182. Izaki, S.; Narukawa, S.; Kubota, A.; Mitsui, T.; Fukaura, H.; Nomura, K. A case of neuromyelitis optica spectrum disorder developing a fulminant course with multiple white-matter lesions following fingolimod treatment. Clin. Neurol. 2013, 53, 513-517. [CrossRef]

183. Tanaka, M.; Oono, M.; Motoyama, R.; Tanaka, K. Longitudinally extensive spinal cord lesion after initiation, and multiple extensive brain lesions after cessation of fingolimod treatment in a patient with recurrent myelitis and anti-aquaporin 4 antibodies. Clin. Exp. Neuroimmunol. 2013, 4, 239-240. [CrossRef]

184. Matsushita, T.; Tateishi, T.; Isobe, N.; Yonekawa, T.; Yamasaki, R.; Matsuse, D.; Murai, H.; Kira, J.-I. Characteristic cerebrospinal fluid cytokine/chemokine profiles in neuromyelitis optica, relapsing remitting or primary progressive multiple sclerosis. PLoS One 2013, 8, e61835. [CrossRef] [PubMed]

185. Lee, H.; Deng, J.; Kujawski, M.; Yang, C.; Liu, Y.; Herrmann, A.; Kortylewski, M.; Horne, D.; Somlo, G.; Forman, S.; et al. STAT3-induced S1PR1 expression is crucial for persistent STAT3 activation in tumors. Nat. Med. 2010, 16, 1421-1428. [CrossRef] [PubMed] 
186. Liang, J.; Nagahashi, M.; Kim, E.Y.; Harikumar, K.B.; Yamada, A.; Huang, W.-C.; Hait, N.C.; Allegood, J.C.; Price, M.M.; Avni, D.; et al. Sphingosine-1-phosphate links persistent STAT3 activation, chronic intestinal inflammation, and development of colitis-associated cancer. Cancer Cell 2013, 23, 107-120. [CrossRef] [PubMed]

187. Nguyen, A.V.; Wu, Y.Y.; Liu, Q.; Wang, D.; Nguyen, S.; Loh, R.; Pang, J.; Friedman, K.; Orlofsky, A.; Augenlicht, L.; et al. STAT3 in epithelial cells regulates inflammation and tumor progression to malignant state in colon. Neoplasia 2013, 15, 998-1008. [CrossRef]

188. Nguyen-Jackson, H.; Panopoulos, A.D.; Zhang, H.; Li, H.S.; Watowich, S.S. STAT3 controls the neutrophil migratory response to CXCR2 ligands by direct activation of G-CSF-induced CXCR2 expression and via modulation of CXCR2 signal transduction. Blood 2010, 115, 3354-3363. [CrossRef]

189. McLoughlin, R.M.; Jenkins, B.J.; Grail, D.; Williams, A.S.; Fielding, C.A.; Parker, C.R.; Ernst, M.; Topley, N.; Jones, S.A. IL-6 trans-signaling via STAT3 directs T cell infiltration in acute inflammation. Proc. Natl. Acad. Sci. USA 2005, 102, 9589-9594. [CrossRef]

190. Yopp, A.C.; Ochando, J.C.; Mao, M.; Ledgerwood, L.; Ding, Y.; Bromberg, J.S. Sphingosine 1-phosphate receptors regulate chemokine-driven transendothelial migration of lymph node but not splenic $\mathrm{T}$ cells. J. Immunol. 2005, 175, 2913-2924. [CrossRef]

191. Harikumar, K.B.; Yester, J.W.; Surace, M.J.; Oyeniran, C.; Price, M.M.; Huang, W.-C.; Hait, N.C.; Allegood, J.C.; Yamada, A.; Kong, X.; et al. K63-linked polyubiquitination of transcription factor IRF1 is essential for IL-1-induced production of chemokines CXCL10 and CCL5. Nat. Immunol. 2014, 15, 231-238. [CrossRef]

192. Uzawa, A.; Mori, M.; Arai, K.; Sato, Y.; Hayakawa, S.; Masuda, S.; Taniguchi, J.; Kuwabara, S. Cytokine and chemokine profiles in neuromyelitis optica: Significance of interleukin-6. Mult. Scler. 2010, 16, 1443-1452. [CrossRef]

193. Muscal, E.; Brey, R.L. Neurologic manifestations of systemic lupus erythematosus in children and adults. Neurol. Clin. 2010, 28, 61-73. [CrossRef] [PubMed]

194. Kirshner, H.S. Hashimoto's encephalopathy: A brief review. Curr. Neurol. Neurosci. Rep. 2014, 14, 476. [CrossRef]

195. Sanna, G.; Piga, M.; Terryberry, J.W.; Peltz, M.T.; Giagheddu, S.; Satta, L.; Ahmed, A.; Cauli, A.; Montaldo, C.; Passiu, G.; et al. Central nervous system involvement in systemic lupus erythematosus: Cerebral imaging and serological profile in patients with and without overt neuropsychiatric manifestations. Lupus 2000, 9, 573-583. [CrossRef] [PubMed]

196. Snider, A.J. Sphingosine kinase and sphingosine-1-phosphate: Regulators in autoimmune and inflammatory disease. Int. J. Clin. Rheumtol. 2013, 8, 453-463. [CrossRef] [PubMed]

197. Okazaki, H.; Hirata, D.; Kamimura, T.; Sato, H.; Iwamoto, M.; Yoshio, T.; Masuyama, J.; Fujimura, A.; Kobayashi, E.; Kano, S.; et al. Effects of FTY720 in MRL-lpr/lpr mice: Therapeutic potential in systemic lupus erythematosus. J. Rheumatol. 2002, 29, 707-716. [PubMed]

198. Alperovich, G.; Rama, I.; Lloberas, N.; Franquesa, M.; Poveda, R.; Gomà, M.; Herrero-Fresneda, I.; Cruzado, J.M.; Bolaños, N.; Carrera, M.; et al. New immunosuppresor strategies in the treatment of murine lupus nephritis. Lupus 2007, 16, 18-24. [CrossRef]

199. Ando, S.; Amano, H.; Amano, E.; Minowa, K.; Watanabe, T.; Nakano, S.; Nakiri, Y.; Morimoto, S.; Tokano, Y.; Lin, Q.; et al. FTY720 exerts a survival advantage through the prevention of end-stage glomerular inflammation in lupus-prone BXSB mice. Biochem. Biophys. Res. Commun. 2010, 394, 804-810. [CrossRef]

200. Wenderfer, S.E.; Stepkowski, S.M.; Braun, M.C. Increased survival and reduced renal injury in MRL/lpr mice treated with a novel sphingosine-1-phosphate receptor agonist. Kidney Int. 2008, 74, 1319-1326. [CrossRef]

201. Han, C.; He, X.; Xia, X.; Guo, J.; Liu, A.; Liu, X.; Wang, X.; Li, C.; Peng, S.; Zhao, W.; et al. Sphk1/S1P/S1PR1 Signaling is involved in the development of autoimmune thyroiditis in patients and NOD.H-2 ${ }^{\mathrm{h} 4}$ mice. Thyroid 2019, 29, 700-713. [CrossRef]

202. Yilmaz, G.; Arumugam, T.V.; Stokes, K.Y.; Granger, D.N. Role of T lymphocytes and interferon- $\gamma$ in ischemic stroke. Circulation 2006, 113, 2105-2112. [CrossRef]

203. Lo, E.H. T time in the brain. Nat. Med. 2009, 15, 844-846. [CrossRef] [PubMed]

204. Shichita, T.; Sugiyama, Y.; Ooboshi, H.; Sugimori, H.; Nakagawa, R.; Takada, I.; Iwaki, T.; Okada, Y.; Iida, M.; Cua, D.J.; et al. Pivotal role of cerebral interleukin-17-producing $\gamma \delta \mathrm{T}$ cells in the delayed phase of ischemic brain injury. Nat. Med. 2009, 15, 946-950. [CrossRef] [PubMed] 
205. Iadecola, C.; Anrather, J. The immunology of stroke: From mechanisms to translation. Nat. Med. 2011, 17, 796-808. [CrossRef] [PubMed]

206. Hurn, P.D.; Subramanian, S.; Parker, S.M.; Afentoulis, M.E.; Kaler, L.J.; Vandenbark, A.A.; Offner, H. T- and B-cell-deficient mice with experimental stroke have reduced lesion size and inflammation. J. Cereb. Blood Flow Metab. 2007, 27, 1798-1805. [CrossRef] [PubMed]

207. Kleinschnitz, C.; Schwab, N.; Kraft, P.; Hagedor, I.; Dreykluft, A.; Schwarz, T.; Austinat, M.; Nieswandt, B.; Wiendl, H.; Stoll, G. Early detrimental T-cell effects in experimental cerebral ischemia are neither related to adaptive immunity nor thrombus formation. Blood 2010, 115, 3835-3842. [CrossRef]

208. Adachi, K.; Kohara, T.; Nakao, N.; Arita, M.; Chiba, K.; Mishina, T.; Sazaki, S.; Fujita, T. Design, synthesis, and structure-activity relationships of 2-substituted-2-amino-1,3-propanediols: Discovery of a novel immunosuppressant, FTY720. Bioorganic Med. Chem. Lett. 1995, 5, 853-856. [CrossRef]

209. Brinkmann, V.; Cyster, J.G.; Hla, T. FTY720: Sphingosine 1-phosphate receptor-1 in the control of lymphocyte egress and endothelial barrier function. Am. J. Transplant. 2004, 4, 1019-1025. [CrossRef]

210. Rolland, W.B., II.; Manaenko, A.; Lekic, T.; Hasegawa, Y.; Ostrowski, R.; Tang, J.; Zhang, J.H. FTY720 is neuroprotective and improves functional outcomes after intracerebral hemorrhage in mice. Acta Neurochir. Suppl. 2011, 111, 213-217. [CrossRef]

211. Hasegawa, Y.; Suzuki, H.; Sozen, T.; Rolland, W.; Zhang, J.H. Activation of sphingosine 1-phosphate receptor-1 by FTY720 is neuroprotective after ischemic stroke in rats. Stroke 2010, 41, 368-374. [CrossRef] [PubMed]

212. Czech, B.; Pfeilschifter, W.; Mazaheri-Omrani, N.; Strobel, M.A.; Kahles, T.; Neumann-Haefelin, T.; Rami, A.; Huwiler, A.; Pfeilschifter, J. The immunomodulatory sphingosine 1-phosphate analog FTY720 reduces lesion size and improves neurological outcome in a mouse model of cerebral ischemia. Biochem. Biophys. Res. Commun. 2009, 389, 251-256. [CrossRef]

213. Kraft, P.; Göb, E.; Schuhmann, M.K.; Göbel, K.; Deppermann, C.; Thielmann, I.; Herrmann, A.M.; Lorenz, K.; Brede, M.; Stoll, G.; et al. FTY720 ameliorates acute ischemic stroke in mice by reducing thrombo-inflammation but not by direct neuroprotection. Stroke 2013, 44, 3202-3210. [CrossRef] [PubMed]

214. Nazari, M.; Keshavarz, S.; Rafati, A.; Namavar, M.R.; Haghani, M. Fingolimod (FTY720) improves hippocampal synaptic plasticity and memory deficit in rats following focal cerebral ischemia. Brain Res. Bull. 2016, 124, 95-102. [CrossRef] [PubMed]

215. Wei, Y.; Yemisci, M.; Kim, H.-H.; Yung, L.M.; Shin, H.K.; Hwang, S.-K.; Guo, S.; Qin, T.; Alsharif, N.; Brinkmann, V.; et al. Fingolimod provides long-term protection in rodent models of cerebral ischemia. Ann Neurol. 2011, 69, 119-129. [CrossRef] [PubMed]

216. Pfeilschifter, W.; Czech-Zechmeister, B.; Sujak, M.; Mirceska, A.; Koch, A.; Rami, A.; Steinmetz, H.; Foerch, C.; Huwiler, A.; Pfeilschifter, J. Activation of sphingosine kinase 2 is an endogenous protective mechanism in cerebral ischemia. Biochem. Biophys. Res. Commun. 2011, 413, 212-217. [CrossRef]

217. Rolland, W.B.; Lekic, T.; Krafft, P.R.; Hasegawa, Y.; Altay, O.; Hartman, R.; Ostrowski, R.; Manaenko, A.; Tang, J.; Zhang, J.H. Fingolimod reduces cerebral lymphocyte infiltration in experimental models of rodent intracerebral hemorrhage. Exp. Neurol. 2013, 241, 45-55. [CrossRef] [PubMed]

218. Fu, Y.; Zhang, N.; Ren, L.; Yan, Y.; Sun, N.; Li, Y.-J.; Han, W.; Xue, R.; Liu, Q.; Hao, J.; et al. Impact of an immune modulator fingolimod on acute ischemic stroke. Proc. Natl. Acad. Sci. USA 2014, 111, 18315-18320. [CrossRef]

219. Schaphorst, K.L.; Chiang, E.; Jacobs, K.N.; Zaiman, A.; Natarajan, V.; Wigley, F.; Garcia, J.G.N. Role of sphingosine-1 phosphate in the enhancement of endothelial barrier integrity by platelet-released products. Am. J. Physiol. Lung Cell Mol. Physiol. 2003, 285, L258-L267. [CrossRef]

220. Liesz, A.; Zhou, W.; Mracskó, É.; Karcher, S.; Bauer, H.; Schwarting, S.; Sun, L.; Bruder, D.; Stegemann, S.; Cerwenka, A.; et al. Inhibition of lymphocyte trafficking shields the brain against deleterious neuroinflammation after stroke. Brain 2011, 134, 704-720. [CrossRef]

221. Cai, A.; Schlunk, F.; Bohmann, F.; Kahefiolasl, S.; Brunkhorst, R.; Foerch, C.; Pfeilschifter, W. Coadministration of FTY720 and rt-PA in an experimental model of large hemispheric stroke-No influence on functional outcome and blood-brain barrier disruption. Exp. Transl. Stroke Med. 2013, 5, 11. [CrossRef]

222. Sanchez, T. Sphingosine-1-phosphate signaling in endothelial disorders. Curr. Atheroscler. Rep. 2016, 18, 31. [CrossRef] 
223. Brait, V.H.; Tarrasón, G.; Gavaldà, A.; Godessart, N.; Planas, A.M. Selective sphingosine 1-phosphate receptor 1 agonist is protective against ischemia/reperfusion in mice. Stroke 2016, 47, 3053-3056. [CrossRef] [PubMed]

224. Blondeau, N.; Lai, Y.; Tyndall, S.; Popolo, M.; Topalkara, K.; Pru, J.K.; Zhang, L.; Kim, H.; Liao, J.K.; Ding, K.; et al. Distribution of sphingosine kinase activity and mRNA in rodent brain. J. Neurochem. 2007, 103, 509-517. [CrossRef] [PubMed]

225. Billich, A.; Bornancin, F.; Dévay, P.; Mechtcheriakova, D.; Urtz, N.; Baumruker, T. Phosphorylation of the immunomodulatory drug FTY720 by sphingosine kinases. J. Biol. Chem. 2003, 278, 47408-47415. [CrossRef]

226. Wacker, B.K.; Perfater, J.L.; Gidday, J.M. Hypoxic preconditioning induces stroke tolerance in mice via a cascading HIF, sphingosine kinase, and CCL2 signaling pathway. J. Neurochem. 2012, 123, 954-962. [CrossRef] [PubMed]

227. Zemann, B.; Kinzel, B.; Müller, M.; Reuschel, R.; Mechtcheriakova, D.; Urtz, N.; Bornancin, F.; Baumruker, T.; Billich, A. Sphingosine kinase type 2 is essential for lymphopenia induced by the immunomodulatory drug FTY720. Blood 2006, 107, 1454-1458. [CrossRef]

228. Wacker, B.K.; Park, T.S.; Gidday, J.M. Hypoxic preconditioning-induced cerebral ischemic tolerance: Role of microvascular sphingosine kinase 2. Stroke 2009, 40, 3342-3348. [CrossRef]

229. Zhang, W.; An, J.; Jawadi, H.; Siow, D.L.; Lee, J.-F.; Zhao, J.; Gartung, A.; Maddipati, K.R.; Honn, K.V.; Wattenberg, B.W.; et al. Sphingosine-1-phosphate receptor-2 mediated NFKB activation contributes to tumor necrosis factor- $\alpha$ induced VCAM-1 and ICAM-1 expression in endothelial cells. Prostaglandins Other Lipid Mediat. 2013, 106, 62-71. [CrossRef]

230. Kim, G.S.; Yang, L.; Zhang, G.; Zhao, H.; Selim, M.; McCullough, L.D.; Kluk, M.J.; Sanchez, T. Critical role of sphingosine-1-phosphate receptor-2 in the disruption of cerebrovascular integrity in experimental stroke. Nat. Commun. 2015, 6, 7893. [CrossRef] [PubMed]

231. Lv, M.; Zhang, D.; Dai, D.; Zhang, W.; Zhang, L. Sphingosine kinase 1/sphingosine-1-phosphate regulates the expression of interleukin-17A in activated microglia in cerebral ischemia/reperfusion. Inflamm. Res. 2016, 65, 551-562. [CrossRef]

232. Zheng, S.; Wei, S.; Wang, X.; Xu, Y.; Xiao, Y.; Liu, H.; Jia, J.; Cheng, J. Sphingosine kinase 1 mediates neuroinflammation following cerebral ischemia. Exp. Neurol. 2015, 272, 160-169. [CrossRef] [PubMed]

233. Campos, F.; Qin, T.; Castillo, J.; Seo, J.H.; Arai, K.; Lo, E.H.; Waeber, C. Fingolimod reduces hemorrhagic transformation associated with delayed tissue plasminogen activator treatment in a mouse thromboembolic model. Stroke 2013, 44, 505-511. [CrossRef] [PubMed]

234. Zhu, Z.; Fu, Y.; Tian, D.; Sun, N.; Han, W.; Chang, G.; Dong, Y.; Xu, X.; Liu, Q.; Huang, D.; et al. Combination of the immune modulator fingolimod with alteplase in acute ischemic stroke: A pilot trial. Circulation 2015, 132, 1104-1112. [CrossRef] [PubMed]

235. Zhang, S.; Zhou, Y.; Zhang, R.; Zhang, M.; Campbell, B.; Lin, L.; Shi, F.-D.; Lou, M. Rationale and design of combination of an immune modulator fingolimod with alteplase bridging with mechanical thrombectomy in acute ischemic stroke (FAMTAIS) trial. Int. J. Stroke 2017, 12, 906-909. [CrossRef] [PubMed]

236. Wan, Y.; Jin, H.-J.; Zhu, Y.-Y.; Fang, Z.; Mao, L.; He, Q.; Xia, J.-P.; Li, M.; Li, Y.; Chen, X.; et al. MicroRNA-149-5p regulates blood-brain barrier permeability after transient middle cerebral artery occlusion in rats by targeting S1PR2 of pericytes. FASEB J. 2018, 32, 3133-3148. [CrossRef] [PubMed]

237. Swendeman, S.L.; Xiong, Y.; Cantalupo, A.; Yuan, A.; Burg, N.; Hisano, Y.; Cartier, A.; Liu, C.H.; Engelbrecht, E.; Blaho, V.; et al. An engineered S1P chaperone attenuates hypertension and ischemic injury. Sci. Signal. 2017, 10, eaal2722. [CrossRef] [PubMed]

238. Testai, F.D.; Kilkus, J.P.; Berdyshev, E.; Gorshkova, I.; Natarajan, V.; Dawson, G. Multiple sphingolipid abnormalities following cerebral microendothelial hypoxia. J. Neurochem. 2014, 131, 530-540. [CrossRef] [PubMed]

239. Gaire, B.P.; Lee, C.H.; Sapkota, A.; Lee, S.Y.; Chun, J.; Cho, H.J.; Nam, T.-G.; Choi, J.W. Identification of sphingosine 1-phosphate receptor subtype 1 (S1P1) as a pathogenic factor in transient focal cerebral ischemia. Mol. Neurobiol. 2018, 55, 2320-2332. [CrossRef]

240. Gaire, B.P.; Song, M.-R.; Choi, J.W. Sphingosine 1-phosphate receptor subtype 3 (S1P3) contributes to brain injury after transient focal cerebral ischemia via modulating microglial activation and their M1 polarization. J. Neuroinflammation 2018, 15, 284. [CrossRef]

241. Gaire, B.P.; Bae, Y.J.; Choi, J.W. S1P1 regulates M1/M2 polarization toward brain injury after transient focal cerebral ischemia. Biomol. Ther. 2019, 27, 522-529. [CrossRef] 
242. Zamanian, J.L.; Xu, L.; Foo, L.C.; Nouri, N.; Zhou, L.; Giffard, R.G.; Barres, B.A. Genomic analysis of reactive astrogliosis. J. Neurosci. 2012, 32, 6391-6410. [CrossRef]

243. Liddelow, S.A.; Guttenplan, K.A.; Clarke, L.E.; Bennett, F.C.; Bohlen, C.J.; Schirmer, L.; Bennett, M.L.; Münch, A.E.; Chung, W.-S.; Peterson, T.C.; et al. Neurotoxic reactive astrocytes are induced by activated microglia. Nature 2017, 541, 481-487. [CrossRef] [PubMed]

244. Anelli, V.; Bassi, R.; Tettamanti, G.; Viani, P.; Riboni, L. Extracellular release of newly synthesized sphingosine-1-phosphate by cerebellar granule cells and astrocytes. J. Neurochem. 2005, 92, 1204-1215. [CrossRef] [PubMed]

245. Mullershausen, F.; Craveiro, L.M.; Shin, Y.; Cortes-Cros, M.; Bassilana, F.; Osinde, M.; Wishart, W.L.; Guerini, D.; Thallmair, M.; Schwab, M.E.; et al. Phosphorylated FTY720 promotes astrocyte migration through sphingosine-1-phosphate receptors. J. Neurochem. 2007, 102, 1151-1161. [CrossRef] [PubMed]

246. Herr, D.R.; Chun, J. Effects of LPA and S1P on the nervous system and implications for their involvement in disease. Curr. Drug Targets 2007, 8, 155-167. [CrossRef] [PubMed]

247. Karunakaran, I.; Alam, S.; Jayagopi, S.; Frohberger, S.J.; Hansen, J.N.; Kuehlwein, J.; Hölbling, B.V.; Schumak, B.; Hübner, M.P.; Gräler, M.H.; et al. Neural sphingosine 1-phosphate accumulation activates microglia and links impaired autophagy and inflammation. Glia 2019, 67, 1859-1872. [CrossRef]

248. Yagi, K.; Lidington, D.; Wan, H.; Fares, J.C.; Meissner, A.; Sumiyoshi, M.; Ai, J.; Foltz, W.D.; Nedospasov, S.A.; Offermanns, S.; et al. Therapeutically targeting tumor necrosis factor- $\alpha /$ sphingosine-1-phosphate signaling corrects myogenic reactivity in subarachnoid hemorrhage. Stroke 2015, 46, 2260-2270. [CrossRef]

249. Olsson, T.; Zhi, W.W.; Hojeberg, B.; Kostulas, V.; Jiang, Y.P.; Anderson, G.; Ekre, H.P.; Link, H. Autoreactive T lymphocytes in multiple sclerosis determined by antigen-induced secretion of interferon- $\gamma$. J. Clin. Investig. 1990, 86, 981-985. [CrossRef]

250. Comi, G. Position and practical use of fingolimod in Europe. Clin. Exp. Neuroimmunol. 2014, 5, 19-33. [CrossRef]

251. Camm, J.; Hla, T.; Bakshi, R.; Brinkmann, V. Cardiac and vascular effects of fingolimod: Mechanistic basis and clinical implications. Am. Heart J. 2014, 168, 632-644. [CrossRef]

252. Cohen, J.A.; Barkhof, F.; Comi, G.; Hartung, H.-P.; Khatri, B.O.; Montalba, Y.; Pelletier, J.; Capra, R.; Gallo, P.; Izquierdo, G.; et al. Oral fingolimod or intramuscular interferon for relapsing multiple sclerosis. N. Engl. J. Med. 2010, 362, 402-415. [CrossRef]

253. Arvin, A.M.; Wolinsky, J.S.; Kappos, L.; Morris, M.I.; Reder, A.T.; Tornatore, C.; Gershon, A.; Gershon, M.; Levin, M.J.; Bezuidenhoudt, M.; et al. Varicella-zoster virus infections in patients treated with fingolimod: Risk assessment and consensus recommendations for management. JAMA Neurol. 2015, 72, 31-39. [CrossRef] [PubMed]

254. Kappos, L.; Radue, E.-W.; O’Connor, P.; Polman, C.; Hohlfeld, R.; Calabresi, P.; Selmaj, K.; Agoropoulou, C.; Leyk, M.; Zhang-Auberson, L.; et al. A placebo-controlled trial of oral fingolimod in relapsing multiple sclerosis. N. Engl. J. Med. 2010, 362, 387-401. [CrossRef] [PubMed]

255. Foerch, C.; Friedauer, L.; Bauer, B.; Wolf, T.; Adam, E.H. Severe COVID-19 infection in a patient with multiple sclerosis treated with fingolimod. Mult. Scler. Relat. Disord. 2020, 42, 102180. [CrossRef]

256. Brinkmann, V. Sphingosine 1-phosphate receptors in health and disease: Mechanistic insights from gene deletion studies and reverse pharmacology. Pharmacol. Ther. 2007, 115, 84-105. [CrossRef]

257. Carvajal, R.D.; Merrill, A.H., Jr.; Dials, H.; Barbi, A.; Schwartz, G.K. A phase I clinical study of safingol followed by cisplatin: Promising activity in refractory adrenocortical cancer with novel pharmacology. J. Clin. Oncol. 2006, 24, 13044-13044. [CrossRef]

258. Schwartz, G.K.; Haimovitz-Friedman, A.; Dhupar, S.K.; Ehleiter, D.; Maslak, P.; Lai, L.; Loganzo, F., Jr.; Kelsen, D.P.; Fuks, Z.; Albino, A.P. Potentiation of apoptosis by treatment with the protein kinase C-specific inhibitor safingol in mitomycin C- treated gastric cancer cells. J. Natl. Cancer Inst. 1995, 87, 1394-1399. [CrossRef]

259. Dickson, M.A.; Carvajal, R.D.; Merrill, A.H., Jr.; Gonen, M.; Cane, L.M.; Schwartz, G.K. A phase I clinical trial of safingol in combination with cisplatin in advanced solid tumors. Clin. Cancer Res. 2011, 17, 2484-2492. [CrossRef]

260. Ling, L.-U.; Tan, K.-B.; Lin, H.; Chiu, G.N.C. The role of reactive oxygen species and autophagy in safingol-induced cell death. Cell Death Dis. 2011, 2, e129. [CrossRef] 
261. French, K.J.; Zhuang, Y.; Maines, L.W.; Gao, P.; Wang, W.; Beljanski, V.; Upson, J.J.; Green, C.L.; Keller, S.N.; Smith, C.D. Pharmacology and antitumor activity of ABC294640, a selective inhibitor of sphingosine kinase-2. J. Pharmacol. Exp. Ther. 2010, 333, 129-139. [CrossRef]

262. Chaurasia, B.; Summers, S.A. Ceramides - Lipotoxic inducers of metabolic disorders. Trends Endocrinol. Metab. 2015, 26, 538-550. [CrossRef]

263. Britten, C.D.; Garrett-Mayer, E.; Chin, S.H.; Shirai, K.; Ogretmen, B.; Bentz, T.A.; Brisendine, A.; Anderton, K.; Cusack, S.L.; Maines, L.W.; et al. A phase I study of ABC294640, a first-in-class sphingosine kinase-2 inhibitor, in patients with advanced solid tumors. Clin. Cancer Res. 2017, 23, 4642-4650. [CrossRef]

264. Xun, C.; Chen, M.-B.; Qi, L.; Tie-Ning, Z.; Peng, X.; Ning, L.; Zhi-Xiao, C.; Li-Wei, W. Targeting sphingosine kinase 2 (SphK2) by ABC294640 inhibits colorectal cancer cell growth in vitro and in vivo. J. Exp. Clin. Cancer Res. 2015, 34, 94. [CrossRef] [PubMed]

265. Xu, L.; Jin, L.; Yang, B.; Wang, L.; Xia, Z.; Zhang, Q.; Xu, J. The sphingosine kinase 2 inhibitor ABC294640 inhibits cervical carcinoma cell growth. Oncotarget 2018, 9, 2384-2394. [CrossRef] [PubMed]

266. Dai, L.; Smith, C.D.; Foroozesh, M.; Miele, L.; Qin, Z. The sphingosine kinase 2 inhibitor ABC294640 displays anti-non-small cell lung cancer activities in vitro and in vivo. Int. J. Cancer 2018, 142, 2153-2162. [CrossRef] [PubMed]

267. Abuhusain, H.J.; Matin, A.; Qiao, Q.; Shen, H.; Kain, N.; Day, B.W.; Stringer, B.W.; Daniels, B.; Laaksonen, M.A.; Teo, C.; et al. A metabolic shift favoring sphingosine 1-phosphate at the expense of ceramide controls glioblastoma angiogenesis. J. Biol. Chem. 2013, 288, 37355-37364. [CrossRef]

268. Mahajan-Thakur, S.; Bien-Möller, S.; Marx, S.; Schroeder, H.; Rauch, B.H. Sphingosine 1-phosphate (S1P) signaling in glioblastoma multiforme-A systematic review. Int. J. Mol. Sci. 2017, 18, 2448. [CrossRef]

269. Visentin, B.; Vekich, J.A.; Sibbald, B.J.; Cavalli, A.L.; Moreno, K.M.; Matteo, R.G.; Garland, W.A.; Lu, Y.; Hall, H.S.; et al. Validation of an anti-sphingosine-1-phosphate antibody as a potential therapeutic in reducing growth, invasion, and angiogenesis in multiple tumor lineages. Cancer Cell 2006, 9, 225-238. [CrossRef]

270. Caballero, S.; Swaney, J.; Moreno, K.; Afzal, A.; Kielczewski, J.; Stoller, G.; Cavalli, A.; Garland, W.; Hansen, G.; Sabbadini, R.; et al. Anti-sphingosine-1-phosphate monoclonal antibodies inhibit angiogenesis and sub-retinal fibrosis in a murine model of laser-induced choroidal neovascularization. Exp. Eye Res. 2009, 88, 367-377. [CrossRef]

271. Sabbadini, R.A. Sphingosine-1-phosphate antibodies as potential agents in the treatment of cancer and age-related macular degeneration. Br. J. Pharmacol. 2011, 162, 1225-1238. [CrossRef]

272. Pal, S.K.; Drabkin, H.A.; Reeves, J.A.; Hainsworth, J.D.; Hazel, S.E.; Paggiarino, D.A.; Wojciak, J.; Woodnutt, G.; Bhatt, R.S. A phase 2 study of the sphingosine-1-phosphate antibody sonepcizumab in patients with metastatic renal cell carcinoma. Cancer 2017, 123, 576-582. [CrossRef]

273. Fleischmann, R. Novel small-molecular therapeutics for rheumatoid arthritis. Curr. Opin. Rheumatol. 2012, 24, 335-341. [CrossRef] [PubMed]

274. Pyszko, J.A.; Strosznajder, J.B. The key role of sphingosine kinases in the molecular mechanism of neuronal cell survival and death in an experimental model of Parkinson's disease. Folia Neuropathol. 2014, 52, 260-269. [CrossRef]

275. Samuvel, D.J.; Saxena, N.; Dhindsa, J.S.; Singh, A.K.; Gill, G.S.; Grobelny, D.W.; Singh, I. AKP-11 - A novel $\mathrm{S} 1 \mathrm{P} 1$ agonist with favorable safety profile attenuates experimental autoimmune encephalomyelitis in rat model of multiple sclerosis. PLoS ONE 2015, 10, e0141781. [CrossRef] [PubMed]

276. Dhar, T.G.M.; Xiao, H.-Y.; Xie, J.; Lehman-McKeeman, L.D.; Wu, D.-R.; Dabros, M.; Yang, X.; Taylor, T.L.; Zhou, X.D.; Heimrich, E.M.; et al. Identification and preclinical pharmacology of BMS-986104: A differentiated S1P1 receptor modulator in clinical trials. ACS Med. Chem. Lett. 2016, 7, 283-288. [CrossRef] [PubMed]

277. Piali, L.; Birker-Robaczewska, M.; Lescop, C.; Froidevaux, S.; Schmitz, N.; Morrison, K.; Kohl, C.; Rey, M.; Studer, R.; Vezzali, E.; et al. Cenerimod, a novel selective S1P1 receptor modulator with unique signaling properties. Pharmacol. Res. Perspect. 2017, 5, e00370. [CrossRef] [PubMed]

278. Hermann, V.; Batalov, A.; Smakotina, S.; Juif, P.E.; Cornelisse, P. First use of cenerimod, a selective S1P 1 receptor modulator, for the treatment of SLE: A double-blind, randomised, placebo-controlled, proof-of-concept study. Lupus Sci. Med. 2019, 6, e000354. [CrossRef]

279. Xu, J.; Gray, F.; Henderson, A.; Hicks, K.; Yang, J.; Thompson, P.; Oliver, J. Safety, pharmacokinetics, pharmacodynamics, and bioavailability of GSK2018682, a sphingosine-1-phosphate receptor modulator, in healthy volunteers. Clin. Pharmacol. Drug Dev. 2014, 3, 170-178. [CrossRef] 
280. Gruessner, R.W.; Sutherland, D.E.; Troppmann, C.; Benedetti, E.; Hakim, N.; Dunn, D.L.; Gruessner, A.C. The surgical risk of pancreas transplantation in the cyclosporine era: An overview. J. Am. Coll. Surg. 1997, 185, 128-144. [CrossRef]

281. Khattar, M.; Deng, R.; Kahan, B.D.; Schroder, P.M.; Phan, T.; Rutzky, L.P.; Stepkowski, S.M. Novel sphingosine-1-phosphate receptor modulator KRP203 combined with locally delivered regulatory T cells induces permanent acceptance of pancreatic islet allografts. Transplantation 2013, 95, 919-927. [CrossRef]

282. D'Ambrosio, D.; Freedman, M.S.; Prinz, J. Ponesimod, a selective S1P1 receptor modulator: A potential treatment for multiple sclerosis and other immune-mediated diseases. Ther. Adv. Chronic Dis. 2016, 7, 18-33. [CrossRef]

283. Schmidt, K.G.; Herrero San Juan, M.; Trautmann, S.; Berninger, L.; Schwiebs, A.; Ottenlinger, F.M.; Thomas, D.; Zaucke, F.; Pfeilschifter, J.M.; Radeke, H.H. Sphingosine-1-phosphate receptor 5 modulates early-stage processes during fibrogenesis in a mouse model of systemic sclerosis: A pilot study. Front. Immunol. 2017, 8, 1242. [CrossRef] [PubMed]

284. Kurata, H.; Kusumi, K.; Otsuki, K.; Suzuki, R.; Kurono, M.; Komiya, T.; Hagiya, H.; Mizuno, H.; Shioya, H.; Ono, T.; et al. Discovery of a 1-Methyl-3,4-dihydronaphthalene-based sphingosine-1-phosphate (S1P) receptor agonist ceralifimod (ONO-4641). A S1P1 and S1P5 selective agonist for the treatment of autoimmune diseases. J. Med. Chem. 2017, 60, 9508-9530. [CrossRef] [PubMed]

285. Meadows, K.R.T.; Steinberg, M.W.; Clemons, B.; Stokes, M.E.; Opiteck, G.J.; Peach, R.; Scott, F.L. Ozanimod (RPC1063), a selective S1PR1 and S1PR5 modulator, reduces chronic inflammation and alleviates kidney pathology in murine systemic lupus erythematosus. PLoS ONE 2018, 13, e0193236. [CrossRef]

286. Wang, W.; Graeler, M.H.; Goetzl, E.J. Type 4 sphingosine 1-phosphate G protein-coupled receptor (S1P4) transduces S1P effects on $\mathrm{T}$ cell proliferation and cytokine secretion without signaling migration. FASEB J. 2005, 19, 1731-1733. [CrossRef]

287. Wang, W.; Huang, M.-C.; Goetzl, E.J. Type 1 sphingosine 1-phosphate G protein-coupled receptor (S1P1) mediation of enhanced IL-4 generation by CD4 T cells from S1P1 transgenic mice. J. Immunol. 2007, 178, 4885-4890. [CrossRef]

288. Gräler, M.H.; Grosse, R.; Kusch, A.; Kremmer, E.; Gudermann, T.; Lipp, M. The sphingosine 1-phosphate receptor S1P4 regulates cell shape and motility via coupling to Gi and G12/13. J. Cell Biochem. 2003, 89, 507-519. [CrossRef]

289. Schulze, T.; Golfier, S.; Tabeling, C.; Räbel, K.; Gräler, M.H.; Witzenrath, M.; Lipp, M. Sphingosine-1-phospate receptor $4(\mathrm{~S} 1 \mathrm{P} 4)$ deficiency profoundly affects dendritic cell function and $\mathrm{TH} 17$-cell differentiation in a murine model. FASEB J. 2011, 25, 4024-4036. [CrossRef]

290. Sugahara, K.; Maeda, Y.; Shimano, K.; Mogami, A.; Kataoka, H.; Ogawa, K.; Hikida, K.; Kumagai, H.; Asayama, M.; Yamamoto, T.; et al. Amiselimod, a novel sphingosine 1-phosphate receptor-1 modulator, has potent therapeutic efficacy for autoimmune diseases, with low bradycardia risk. Br. J. Pharmacol. 2017, 174, 15-27. [CrossRef]

291. Kappos, L.; Arnold, D.L.; Bar-Or, A.; Camm, A.J.; Derfuss, T.; Sprenger, T.; Davies, M.; Piotrowska, A.; Ni, P.; Harada, T. Two-year results from a phase 2 extension study of oral amiselimod in relapsing multiple sclerosis. Mult. Scler. 2018, 24, 1605-1616. [CrossRef]

292. Shimano, K.; Maeda, Y.; Kataoka, H.; Murase, M.; Mochizuki, S.; Utsumi, H.; Oshita, K.; Sugahara, K. Amiselimod (MT-1303), a novel sphingosine 1-phosphate receptor-1 functional antagonist, inhibits progress of chronic colitis induced by transfer of CD4 ${ }^{+}$CD45RBhigh T cells. PLoS ONE 2019, 14, e226154. [CrossRef]

293. Sandborn, W.J.; Peyrin-Biroulet, L.; Zhang, J.; Chiorean, M.; Vermeire, S.; Lee, S.D.; Kühlbacher, T.; Yacyshyn, B.; Cabell, C.H.; Naik, S.U.; et al. Efficacy and safety of etrasimod in a phase 2 randomized trial of patients with ulcerative colitis. Gastroenterology 2020, 158, 550-561. [CrossRef] [PubMed]

(C) 2020 by the authors. Licensee MDPI, Basel, Switzerland. This article is an open access article distributed under the terms and conditions of the Creative Commons Attribution (CC BY) license (http://creativecommons.org/licenses/by/4.0/). 